

\section{A Historical Analysis of Investment in Solar Energy Technologies (2000-2007)}

Charles E. Jennings

Financial Analytics Consulting Corporation

Robert M. Margolis

National Renewable Energy Laboratory

John E. Bartlett

New West Technologies, LLC

Prepared under Subcontract No. AEK-8-888272-01 and Task No. PBV7.6301

\section{Technical Report} NREL/TP-6A2-43602

December 2008

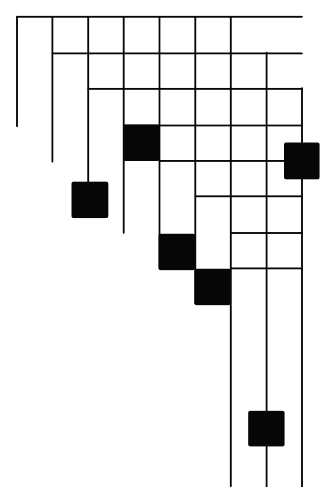




\section{NOTICE}

This report was prepared as an account of work sponsored by an agency of the United States government. Neither the United States government nor any agency thereof, nor any of their employees, makes any warranty, express or implied, or assumes any legal liability or responsibility for the accuracy, completeness, or usefulness of any information, apparatus, product, or process disclosed, or represents that its use would not infringe privately owned rights. Reference herein to any specific commercial product, process, or service by trade name, trademark, manufacturer, or otherwise does not necessarily constitute or imply its endorsement, recommendation, or favoring by the United States government or any agency thereof. The views and opinions of authors expressed herein do not necessarily state or reflect those of the United States government or any agency thereof.

Available electronically at http://www.osti.gov/bridge

Available for a processing fee to U.S. Department of Energy and its contractors, in paper, from:

U.S. Department of Energy

Office of Scientific and Technical Information

P.O. Box 62

Oak Ridge, TN 37831-0062

phone: 865.576 .8401

fax: 865.576 .5728

email: mailto:reports@adonis.osti.gov

Available for sale to the public, in paper, from:

U.S. Department of Commerce

National Technical Information Service

5285 Port Royal Road

Springfield, VA 22161

phone: 800.553 .6847

fax: 703.605.6900

email: orders@ntis.fedworld.gov

online ordering: http://www.ntis.gov/ordering.htm

This publication received minimal editorial review at NREL 


\section{Acknowledgments}

The authors would like to thank the following people for providing helpful comments on draft versions of this report: Doug Arent (National Renewable Energy Laboratory), Drew Bond (Department of Energy - DOE), Jenny Chase (New Energy Finance), Craig Cornelius (Hudson Clean Energy Partners), John Lushetsky (DOE), Michael Molnar (Goldman Sachs), and Scott Stephens (DOE). The authors also are grateful for funding support from the U.S. Department of Energy. 


\section{Table of Contents}

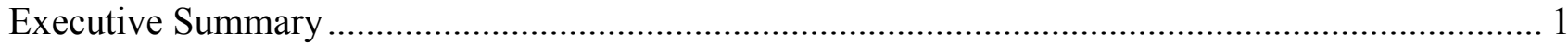

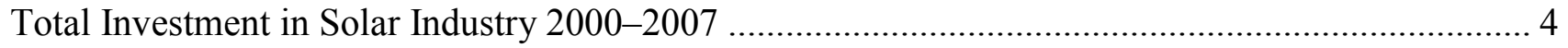

Figure 1. U.S. DOE Solar Technology Development Pipeline.............................................. 4

Figure 2. Positive Feedback for Solar ................................................................................. 5

Figure 3. Global Capital Investments in Solar Energy …................................................ 7

Figure 4. U.S. Capital Investments in Solar Energy ..................................................... 9

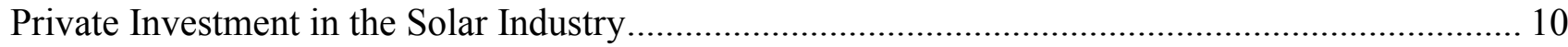

Figure 5: Global Venture Capital Investments in Clean Energy Technologies....................... 10

Figure 6: Global Venture Capital and Private Equity Investments in Solar .......................... 12

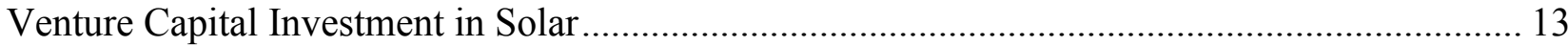

Figure 7: Global Venture Capital Investment in Solar .......................................................... 13

Figure 8: Global Solar Venture Capital Rounds and Average Round Amount ........................ 15

Figure 9: Global Solar Venture Capital Funding by Round Type ....................................... 16

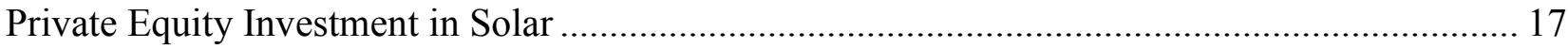

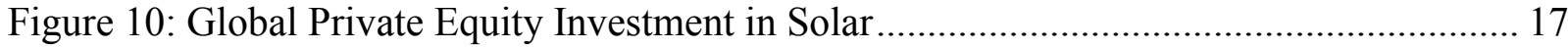

Private Investment by Technology Area................................................................................. 19

Figure 11: Global Venture Capital and Private Equity Investments by Solar Technology ....... 19

Figure 12: Global Venture Capital Investment by Solar Technology ................................... 21

Figure 13: Global Private Equity Investment by Solar Technology ....................................... 22

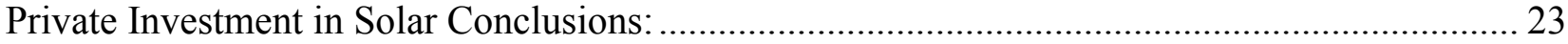

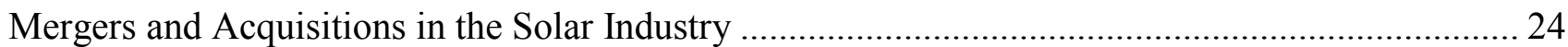

Figure 14: Global Merger and Acquisition Activity in Solar ............................................. 24

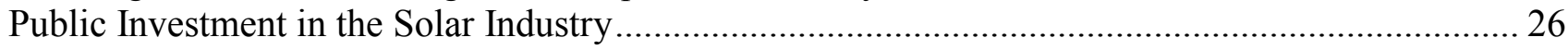

Figure 15: Global Valuations of Completed Solar Public Offerings ...................................... 26

Figure 16: Global Solar Public Offerings by Status ........................................................ 27

Figure 17: Performance of Solar Photovoltaic Stocks .......................................................... 28

Table 1: Public Pure-Play Solar Companies ............................................................................ 29

Figure 18: Global Solar Industry Revenues and Operating Profits .................................... 30

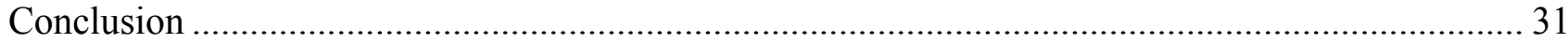

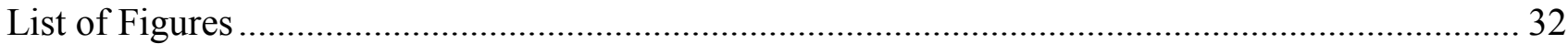

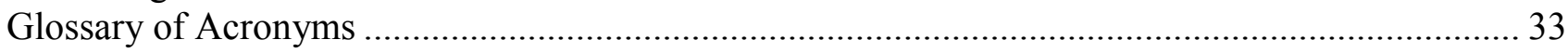




\section{Executive Summary}

The solar energy industry experienced unprecedented growth in the eight years from 2000 to 2007, with explosive growth occurring in the latter half of this period. From 2004 to 2007, global private sector investment in solar energy increased by almost twenty-fold, marking a dramatic increase in the short span of four years.

In this paper, we examine the timing, magnitude, focus and location of various forms of investment in the solar energy sector. We analyze their trends to provide an understanding of the growth of the solar industry during the past eight years and to identify emerging themes in this rapidly evolving industry.

In recent years, solar generation capacity has shifted from an energy source used primarily for remote power at off-grid locations to a viable energy source for those with access to the electricity grid. While the vast majority of demand for solar energy has been directly stimulated by government policy, this market expansion has resulted in major reductions in the cost to supply solar energy and has highlighted a path to future economic competitiveness with other forms of electricity generation. Moreover, solar energy does not bear the environmental and national security external costs associated with fossil and nuclear-based generation. Advanced by early government incentives and R\&D investment, many industry analysts expect solar energy to transition to grid parity within the next three to seven years.

In section 1 of this report, we describe the total investment in the solar industry from 2000 to 2007. The growth in the solar industry during this period reflects a series of complex interactions between the private and public sectors, involving multiple feedback loops. These exchanges have enabled solar technology innovations to progress from the laboratory to the commercial marketplace. Throughout this process, investments from governments, private investors and public equity markets have interacted to help commercialize technology innovations.

Our analysis focuses on venture capital, private equity, mergers and acquisitions and public equity investing activities. These are the types of investment that are having the greatest impact on the solar industry's rapid expansion. The increased levels of investment over the past few years are the result of a mix of underlying factors, including private investment trends, manufacturing scaleup, greater product R\&D, cost reductions, innovations in business and policy models and expanded markets for solar energy products.

During the period 2000-2004, the U.S. Department of Energy Solar Energy Technologies Program (SETP) investment averaged about $50 \%$ of total investment in the U.S. solar sector. However, during the period 2004-2007, total investment in the U.S. solar industry increased at a $145 \%$ compound annual growth rate (CAGR), expanding from $\$ 215$ million to almost $\$ 3.2$ billion. Of course the focus of SETP (applied R\&D) and non-governmental investment (system development, manufacturing expansion, etc.) are quite different. Still, during this period, SETP investment as a percentage of total investment dropped from $50 \%$ to less than $4 \%$. The dramatically increased role of non-governmental investment signals the movement of a range of solar energy 
technology innovations out of government and private R\&D laboratories and into the commercial marketplace.

Two main drivers spurred the growth of non-governmental investments in solar energy in 2005-2007: (1) if projected cost reductions can be achieved, the addressable market for solar energy will be immense, and (2) the previous 30 years of R\&D in solar energy has created a suite of technologies that are now entering or are poised to enter the marketplace. However, it must be noted that government incentive programs stimulate the vast majority of current demand for solar electricity generation equipment. Without the government policies in Japan, Germany, Spain, the U.S. and several other countries, the market for solar energy technologies would only be a fraction of what it is today.

In section 2, we examine private investment in the solar energy industry, including venture capital and private equity financing. In 2007, solar received the largest share of global clean energy venture capital investment, followed by energy efficiency. The total volume of venture capital investments in solar and efficiency (approximately $\$ 2.0$ billion in 2007), has created significant momentum in these industries and will help solar to become an increasingly important source of energy in the near future. The long-term consequences of solar and energy-efficiency improvements will be more abundant and diverse sources of clean and reliable energy and less intensive energy use.

Significant regional differences exist between venture capital and private equity and the technologies they fund. In the United States, venture capital dominates due to the collaboration between scientists and investors pursuing the technologies that will reduce cost, achieve scale and fit different applications across the country, which is potentially the world's largest solar market. Private equity investments in the U.S. could expand considerably if the federal government establishes a cap on carbon emissions or if cost reductions enable solar energy to be more competitive with electricity delivered from the grid.

In Section 3, we examine mergers and acquisitions (M\&A) in the solar industry. These transactions had a deal volume of more than $\$ 1.9$ billion in 2007, but M\&A activities are only beginning to take off. As solar is a new and rapidly growing industry, M\&A could greatly expand due to further entry into the industry by established semiconductor and energy companies as well as integration of solar companies across the supply chain.

In Section 4, we review public equity investment in the solar industry, which has become the largest source of funding for the solar industry. In this section, we also examine publicly-traded solar companies, the performance of solar photovoltaic stocks and the growth of the industry's revenues and operating profits.

Finally, we offer some conclusions on the historical investment trends in solar energy and what they suggest about technological, policy and market developments in the sector. 


\section{Total Investment in Solar Industry 2000-2007}

The solar industry has experienced rapid acceleration in investment across all segments of the value chain during the past eight years. An important difference between solar and many other advanced technologies is that all investments in solar, with the exception of solar water heating, can be viewed primarily as investments in electrical generation capacity. In recent years, solar generation capacity has progressed from an energy source used mostly for remote power at off-grid locations to a viable energy source for those with access to the electricity grid. Stimulated by government policies, this solar market expansion has resulted in major reductions in the cost to supply solar energy, highlighting a path to future economic competitiveness with other forms of electricity generation, particularly when all external costs are taken into account. This report compiles and analyzes the different sources and uses of investments in solar energy, with the objective of clarifying the dynamics currently shaping the rapid evolution of the solar industry.

Investment in solar energy takes many forms, ranging from government research grants for technology development to mergers and acquisitions. However, to understand the different types, timing and purposes of investment, it is useful to illustrate the progression of solar technologies with the U.S. Department of Energy (DOE) Solar America Initiative's technology development pipeline (shown in Figure 1).

\section{Figure 1. U.S. DOE Solar Technology Development Pipeline}

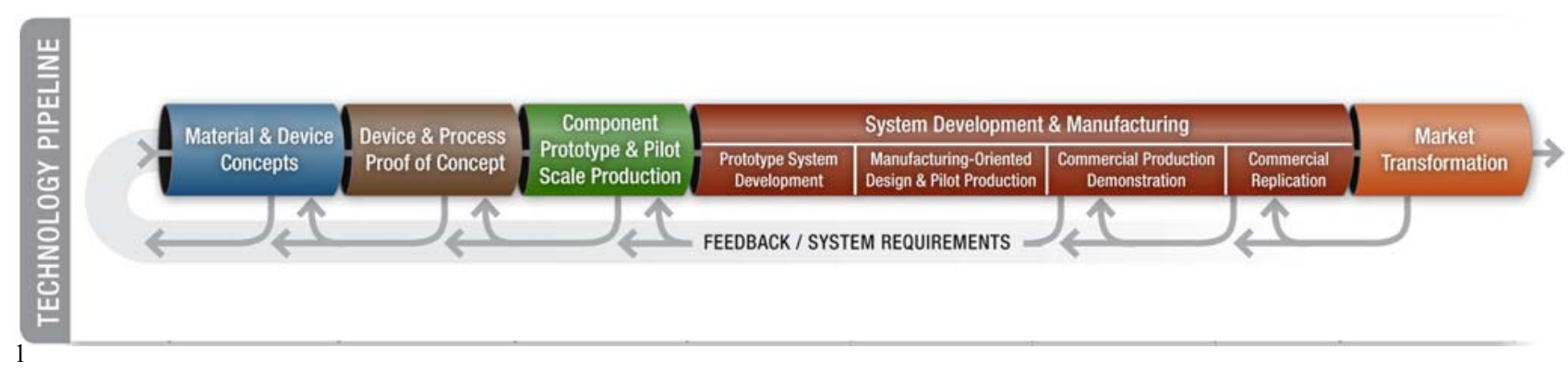

Investments in solar energy can generally be mapped to the technology pipeline in the following manner:

Venture capital investments fund activities in the first four segments of the pipeline: (i) material \& device concepts; (ii) device \& process proof of concept; (iii) component prototype and pilot scale production; and (iv) prototype system development. Venture investments are typically in conjunction with, or as a follow on to, government R\&D investment.

Private equity investments fund activities in all four sections of System Development and Manufacturing: (i) prototype system development; (ii) manufacturing-oriented design and pilot

\footnotetext{
${ }^{1}$ U.S. DOE, SETP, Technology Development Pipeline
} 
production; (iii) commercial production demonstration; and (iv) commercial replication (leading to market transformation).

Investments from public equity, debt and mergers and acquisitions fund activities in the last two segments of the pipeline: (i) commercial replication and (ii) market transformation.

Growth in the solar industry occurs through a series of complex interactions between the private and public sector, involving multiple feedback loops, which has allowed technology innovation to proceed from laboratories to start-up companies. Initial expansion is financed through some combination of governmental and non-governmental funding. Once these companies are commercial, meaning that they have a saleable product available in the marketplace, their further expansion is funded through retained earnings from product sales, larger inflows of private or public equity and corporate debt. These financing mechanisms differ widely depending on the technology, company, market expectations and current market conditions. Growth in the solar industry is illustrated in Figure 2, although the order of steps may vary.

\section{Figure 2. Positive Feedback for Solar}

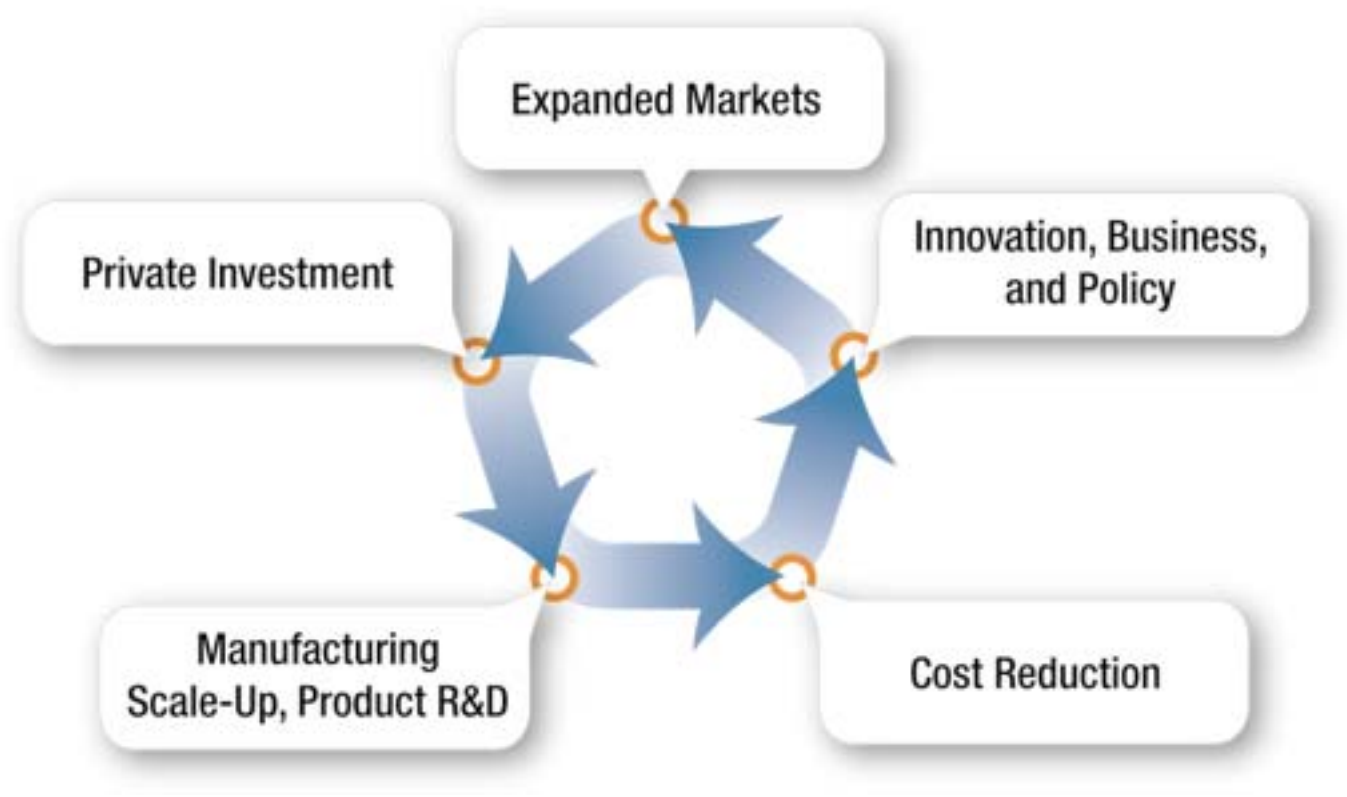

Each of these stages may require different types of investment to progress into the next phase of technology and corporate growth. In this paper, we review seven types of investment for financing corporate growth and consider their current use in funding the development of solar technologies.

The types of investment include:

\footnotetext{
${ }^{2}$ U.S. DOE, SETP, Scott Stephens, Positive Feedback for PV
} 
1. Government Grants: funding from government institutions to universities, companies and laboratories.

2. Venture Capital: independently managed pools of capital that fund start-up firms and small businesses with exceptional growth potential. In return, venture capitalists receive equity stakes and sometimes leadership roles in the company.

3. Private Equity: independently managed pools of capital, also called buyout or mezzanine funds, that purchase entire businesses, or large portions thereof, with exceptional growth or leverage potential. In the solar industry, private equity firms generally underwrite manufacturing expansions and undertake buyouts and corporate spin-offs.

4. Project Finance: funding for the installation of solar energy generation facilities.

5. Debt: Loans from banks or other pools of capital to finance solar energy installations or corporate expansions.

6. Mergers and Acquisitions: transactions involving the purchase of an entire company or a significant interest in a company.

7. Public Equity: public market investments in solar energy companies, in which corporate equity stakes are sold on the open market.

We focus our analysis on venture capital, private equity, mergers and acquisitions and public equity investments, which are having the greatest impact on the solar industry's rapid expansion. Commencing with a global overview of investment activities in the industry, we will subsequently determine and interpret the trends and dynamics shaping capital flows within the industry. This topdown analysis should provide meaningful insights to all investors in the solar sector, from government technology developers to public equity investors. 


\section{Figure 3: Global Capital Investments in Solar Energy*}

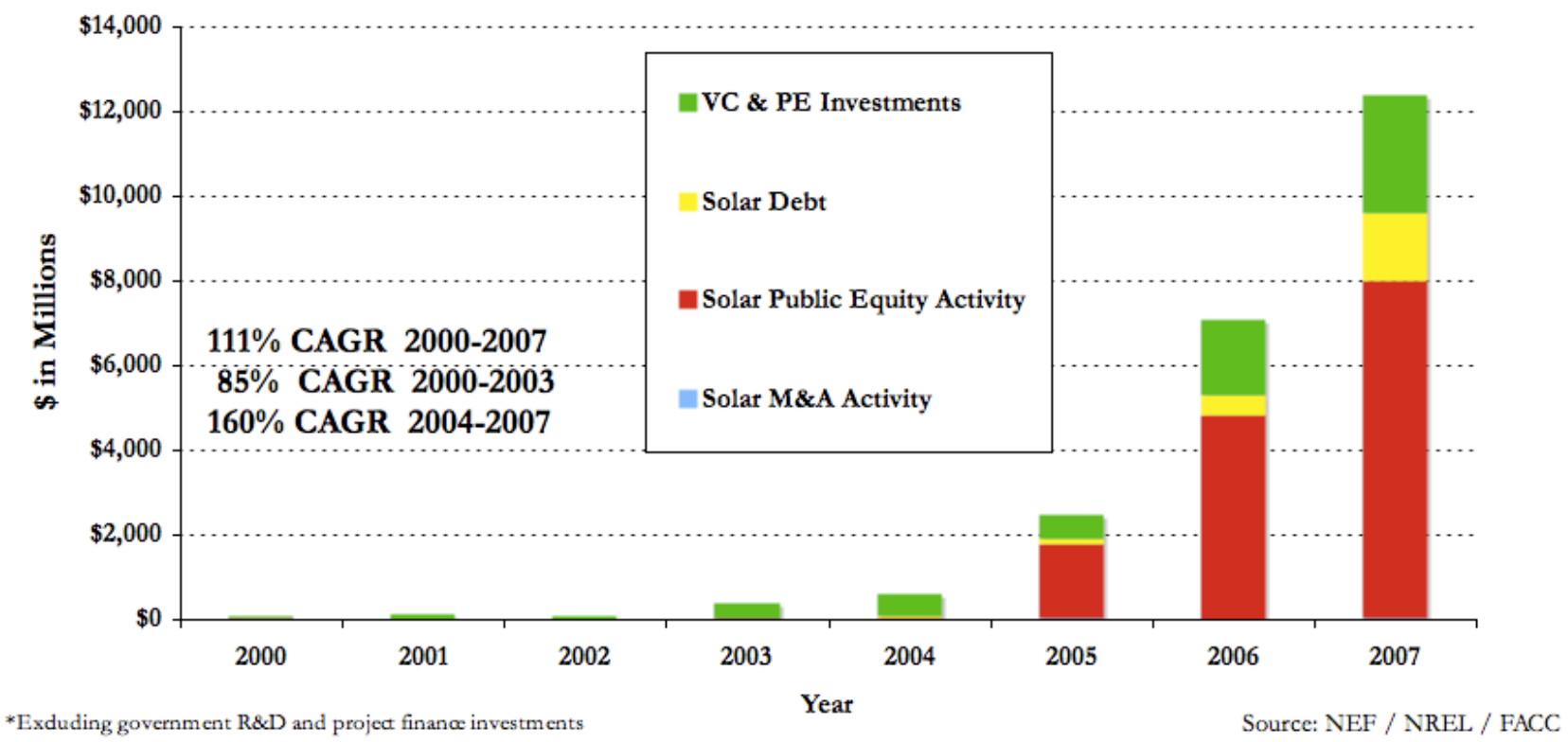

At first glance, Figure 3 seems to imply that global investment in solar energy was minimal from 2000 through 2004. However, it is the scale of the expansion from 2005 through 2007 that dwarfs the previous investment. Total annual investment in 2000 through 2003 was \$66, \$144, \$110 and $\$ 417$ million sequentially, an $85 \%$ CAGR. This investment set the foundation for the rapid expansion of the industry in 2004, as generous incentive programs in Germany and Japan brought solar energy into the mainstream in both countries. Total investment in 2005 of $\$ 2.5$ billion, including \$1.74 billion of public equity, \$604 million of private investment, \$104 million of corporate debt and $\$ 50$ million of equity from M\&A, marked a 256\% increase over total investment in 2004. This was followed by an increase of $183 \%$ to $\$ 7.1$ billion in 2006 and another $75 \%$ increase to $\$ 12.4$ billion in 2007. In the period 2004-2007, total investment in solar energy increased by almost 20-fold, a dramatic expansion in the short span of four years.

The rising levels of investment over the past few years are the result of a mix of underlying factors, with many different mechanisms for positive feedbacks across the solar supply chain. As illustrated in Figure 2, these factors include prior private investment, manufacturing scale-up and product R\&D, cost reductions, innovations in business and policy models and expanded markets for solar energy products.

Because of the significant change in investment between 2004 and 2005, we omit the period from 2000 to 2003 in many parts of this paper unless it is useful to understand trends in solar investment. The period from 2004 through 2007 is sufficient for most of our analysis, and thus many charts are limited as such. Our focus is the analysis of different types of investments to reveal the market dynamics shaping this rapidly expanding industry.

In this paper, government grants are noted but not examined. However, they were responsible for the initial development of many of the current solar technologies. In addition, since government-sponsored R\&D has a high risk/return profile, presently-funded R\&D is likely to yield important technologies in the coming years. 
Debt capital is noted but not examined. Debt capital is just beginning to support the growth of the solar industry, as banks are becoming involved in financing the expansion of manufacturing plants. Greater debt financing is a positive trend, suggesting that the perceived market and technology risks are decreasing. Furthermore, increases in debt financing will allow industry participants to significantly lower their cost of capital. The future availability and cost of debt capital for solar companies and installations is an important issue, but it is outside the historical focus of this paper.

In this paper, project finance is neither listed nor examined. In the United States thus far, project finance has focused on utilizing existing state and federal incentives, in the form of tax credits and accelerated depreciation, to reduce the overall cost of a solar energy system to the end user. In this way, project financing can be viewed as strategic investments by tax-motivated investors to take advantage of the available government subsidies for solar installations. Therefore, an analysis of project finance would reveal more about government incentives than about the evolution of the solar industry.

In addition, the small scale and distributed nature of solar installations means that an analysis of project finance requires considerable detail and includes a large estimation factor. For relevant studies, see Navigant Consulting's annual analysis of solar cell/module shipments and New Energy Finance's analysis of total asset financings. ${ }^{3,4}$

All of the data relating to private investment within this paper are sourced from the New Energy Finance Desktop ${ }^{5}$, the most comprehensive database of publicly-available financial transactions across the emerging energy technology sectors. Although the New Energy Finance Desktop contains only publicly-disclosed transactions and thus will undervalue total investment, the data is appropriate for our analysis of general trends of capital allocation. In certain sections, there are a percentage of deals that have no dollar amount listed, as private investment pools of venture capital and private equity are under no obligation to disclose their activities.

\footnotetext{
${ }^{3}$ http://www.navigantconsulting.com/downloads/PV_Solar_Report07-08.pdf

${ }^{4}$ New Energy Finance, www.newenergyfinance.com

${ }^{5}$ Ibid
} 
Figure 4: U.S. Capital Investments in Solar Energy*

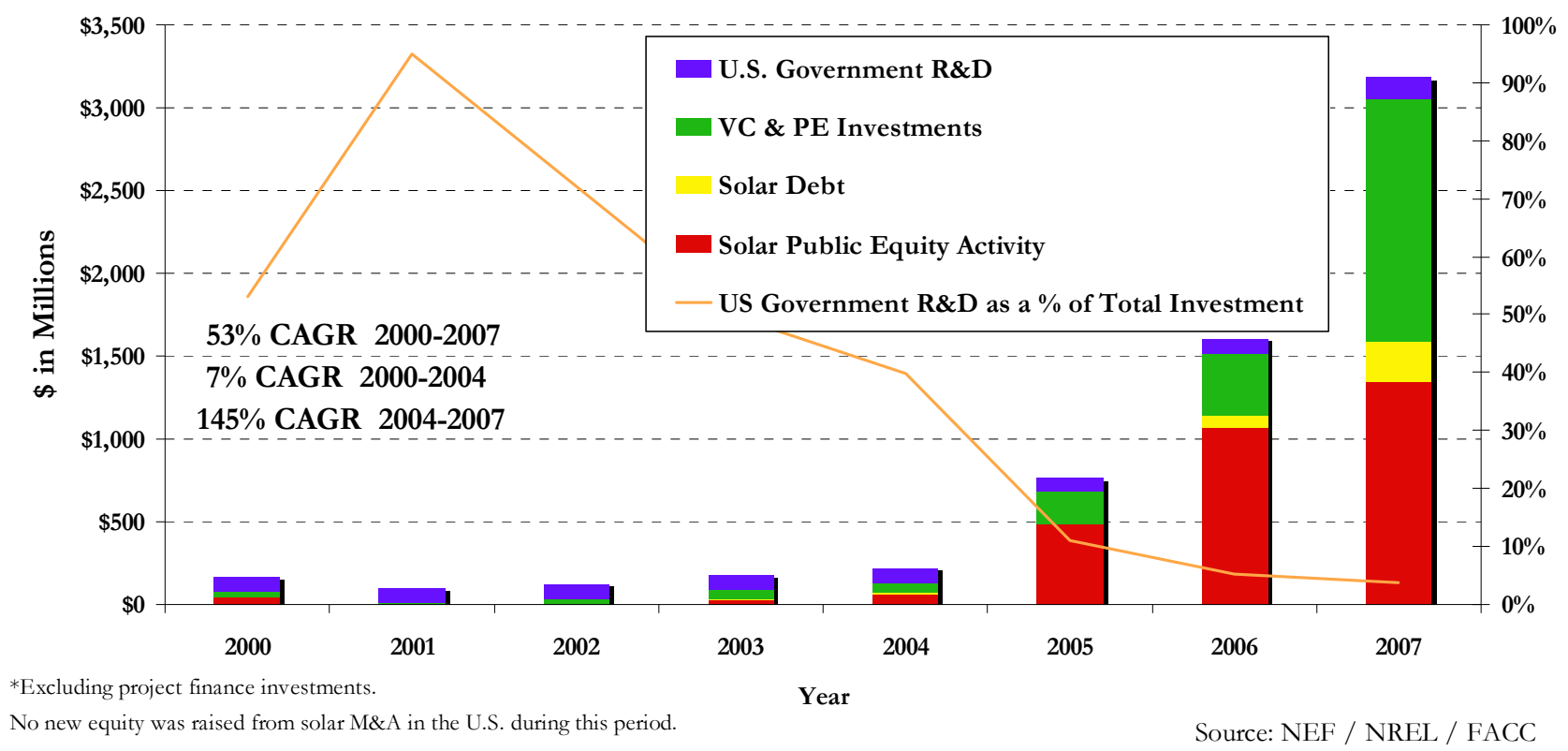

Figure 4 shows investments in solar energy in the United States, including the applied R\&D expenditures of the DOE Solar Energy Technologies Program (SETP). Following a similar pattern as worldwide investment, the chart presents investment during the period 2000-2004 progressing from $\$ 164$ to $\$ 215$ million, a CAGR of $7 \%$. During this period, SETP investment averaged approximately $50 \%$ of total investment in the solar sector. However, during the period 2004-2007, investment in the industry grew at a $145 \%$ CAGR, expanding from \$215 million to almost \$3.2 billion, causing SETP investment as a percentage of total investment to drop to less than 4\% in 2007. This change in investment amounts and types reflects the movement of solar energy technologies out of government and private R\&D laboratories and into the commercial marketplace. The type of investment provides a rough estimate of the readiness of the respective solar technology for the commercial marketplace.

Two main drivers caused the growth of non-governmental investments in solar energy in 2005-2007:

1. If projected cost reductions can be achieved, the addressable market for solar energy will be immense.

2. The previous 30 years of $R \& D$ in solar energy has created a suite of technologies that are now entering or are poised to enter the marketplace. 


\section{Private Investment in the Solar Industry}

\section{Figure 5: Global Venture Capital Investments in Clean Energy Technologies}

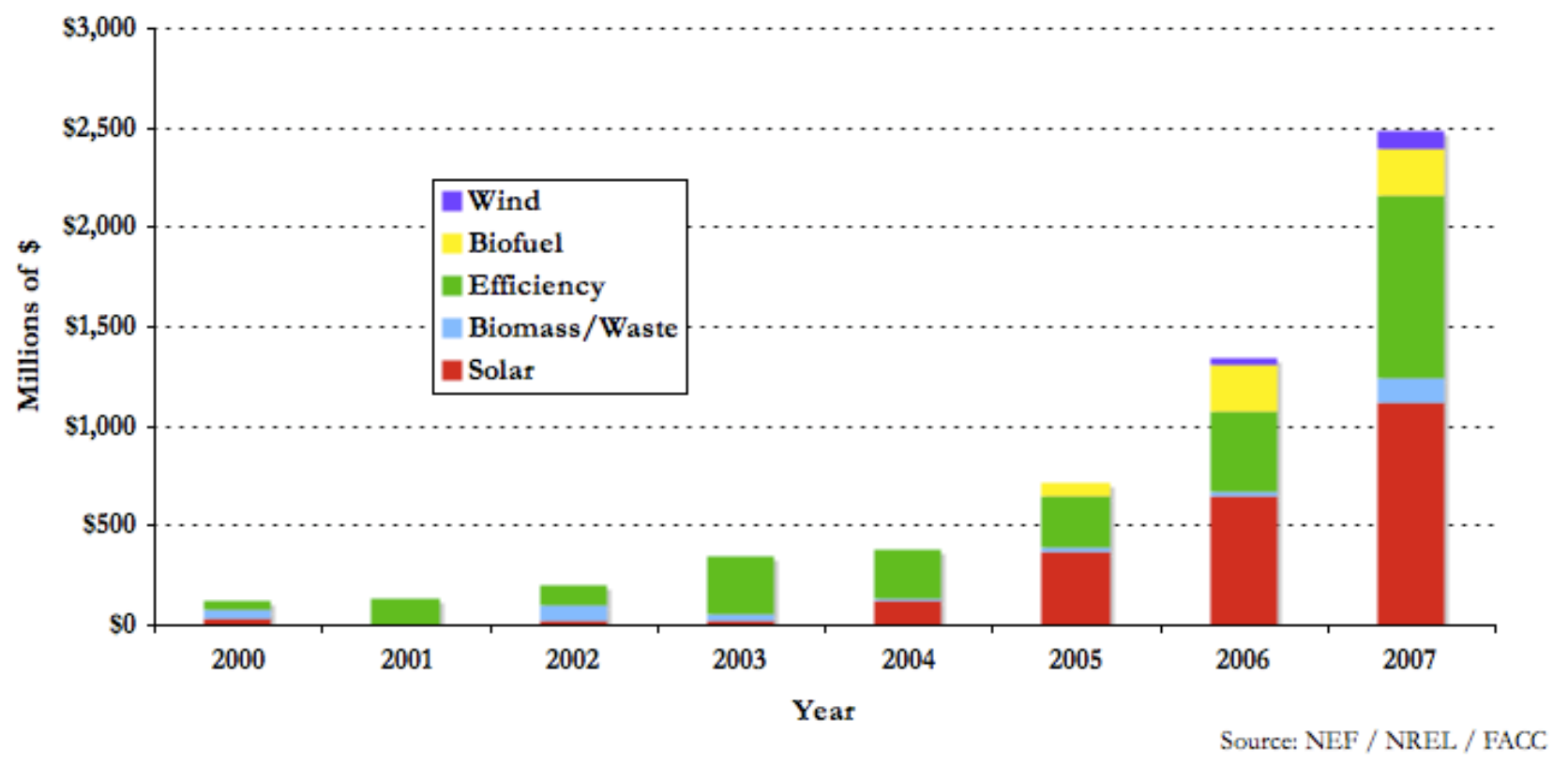

Figure 5 illustrates only venture capital investments, which are early-stage financings of private companies. For comparison, venture capital investments in solar are shown with the top four other areas of venture capital funding within renewable energy and energy efficiency over the past eight years.

Energy efficiency, which includes supply-side and demand-side energy efficiency and energy-efficient building technologies, have received the second-largest share of venture capital investment. Significant improvements in energy efficiency would enable distributed solar power, which is limited by the absence of storage and the area available on building rooftops or other localized production sites, to serve a larger portion of energy demand. The synergies between solar energy and energy efficiency are many and diverse. They include smart electricity grid technologies, which would provide feedback to natural gas peaking units during periods of high energy demand and solar output; energy management technologies, which would allow for storage and/or more efficient timing of energy usage; and plug-in hybrid vehicles, which would enable vehicle-to-grid integration and store solar energy in a mobile asset. All of these technologies would further increase the market share that could be addressed effectively by electricity generation from intermittent resources, such as solar or wind.

Also of note is the limited amount of venture capital investment in wind technologies. This difference is attributable to wind technology already being largely commercialized, and firms are now pursuing large-scale manufacturing expansion. In contrast, the extensive venture capital 
investment in solar is funding innovation in the first four stages of the technology pipeline in order to achieve market breakthroughs. Given the scale of current funding, some of these innovations are likely to prove successful in the next three to five years, as the next generation of solar devices enters the market.

Biofuels have received a great deal of public and media attention during the past few years based on their near-term potential for displacing oil imports for the transportation sector. However, over the past few years biofuels have received less than one-third of the venture capital investment in solar. This difference is likely in part due to the early emphasis on scaling up first-generation biofuels, such as corn-based ethanol, which has been funded instead by project financing and debt. Second and third-generation biofuels, however, are beginning to attract attention from venture capitalists, and increased investments are anticipated for these technologies. However, with a diverse set of potentially successful technological pathways and capabilities in both centralized and distributed applications, solar energy provides a good market for venture capital investment.

The amounts of venture capital investment in solar energy and energy efficiency, in comparison to other clean energy technologies, signals that solar will be an increasingly important source of clean energy in the near future. With momentum gained through growing venture capital support, the advancement of solar and energy-efficiency technologies will likely have long-term consequences for the energy sector, including more diverse and abundant sources of clean energy, greater energy reliability and security and less-intensive energy use. 


\section{Figure 6: Global Venture Capital and Private Equity Investments in Solar}

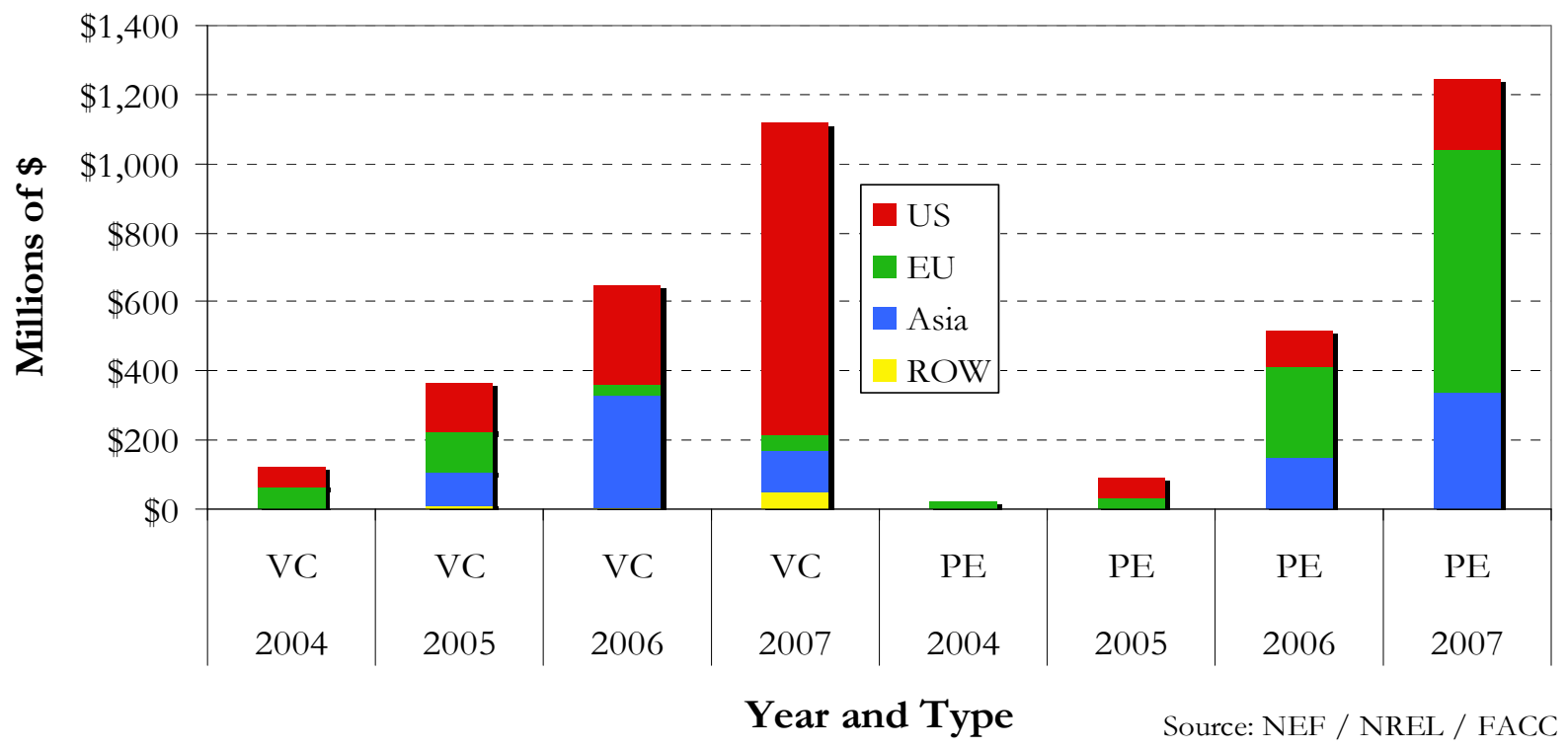

Figure 6 shows the growth of venture capital and private equity investments in solar over the past four years. We focus on 2004-2007, because it is the period when significant changes occurred. While global private equity investment in solar totaled only $\$ 24$ million in 2004, it increased by $272 \%$ in $2005,476 \%$ in 2006 and $142 \%$ in 2007, in which year total private equity investment reached $\$ 1.24$ billion. This was an increase of over 50 -fold in three years. Global venture capital investment in solar has shown somewhat more steady growth, with \$122 million in 2004 and growing by $199 \%$ in $2005,78 \%$ in 2006 and $73 \%$ in 2007 , when it reached $\$ 1.1$ billion.

This chart demonstrates a major theme in the recent history of solar investment, that regional differences in subsidy programs, policies and regulations have produced significant differences in investment patterns. Especially apparent in 2007 was the predominance (57\% of the total) of private equity investment in Europe. The large majority of private equity investments in the solar industry has been to finance capacity expansions (often by means of constructing new factories), thus indicating that companies based in the European Union have been building the majority of these factories. Also apparent in 2007 was the predominance (82\% of the total) of venture capital investment in the United States. Venture capital investment is an indicator of new and/or emerging technologies or business models. Whereas generous subsidy programs in the European Union have spurred companies in the E.U. to expand capacity rapidly, the market in the United States has not been sufficiently attractive to enable significant growth with recent technologies, prices and business models. Therefore, more U.S. investment has been made in innovative technologies with longerterm prospects. In addition, 2007 was the first year with significant investment in companies in the rest of the world (ROW), which in this case included Canada, Israel, Australia, Morocco and South Africa. Investment in these countries is expected to increase in the coming years.

To reveal the financial and geographical trends in greater detail, we subsequently analyze venture capital and private equity investments separately. Finally, we examine venture capital and private equity funding by solar technology. 


\section{Venture Capital Investment in Solar}

\section{Figure 7: Global Venture Capital Investment in Solar}

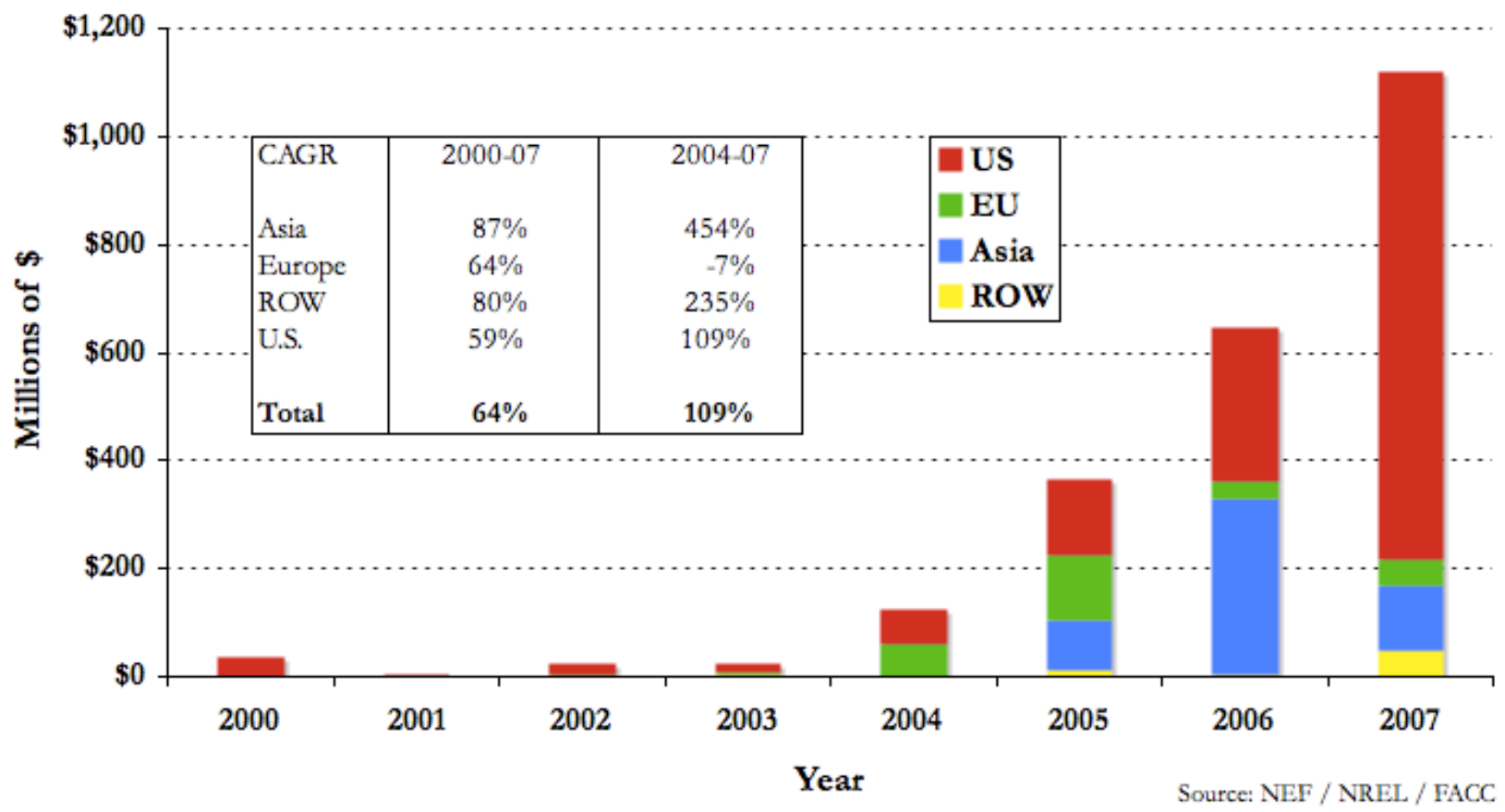

Figure 7 shows that over the past three years, global venture capital investment in solar has grown at a nearly $110 \%$ CAGR. In making regional distinctions, we used the headquarters' location of the company receiving venture capital funding to determine where to allocate the respective investment. It is important to note that $21 \%$ of publicly-disclosed venture capital deals during this period were of undisclosed dollar value, and therefore the numbers in this chart represent a lower bound to global venture capital investment.

In 2004, venture capital investment was split fairly evenly between companies based in the United States and the European Union. However, over the next three years, substantial regional differences emerged. In 2005, venture capital investors started to provide significant financing to Asian firms, while also increasing their investment in European and American start-ups. In 2006, the amount of venture capital investment in Europe had declined precipitously, while American and Asian venture capital funding continued to grow. Finally, in 2007, the first sizeable venture capital investments were made in countries outside of the United States, European Union or Asia, with venture capital funding firms in Israel, Canada and Australia. There was also a decline in venture capital investment to Asian companies in 2007 as U.S. venture capital funds' enthusiasm for starting up crystalline silicon companies in Asia diminished. As venture capital funding to U.S. companies increased dramatically in 2007 during a year of decreased investment in Asia and small totals of venture capital in Europe and ROW, the share of venture capital investment in the U.S. grew to $82 \%$. 
These trends are due to the underlying dynamics within the three primary solar markets, the U.S., Europe and Asia. In the European market, with generous subsidies available in Germany and Spain and nascent carbon markets, demand has grown steadily. Investment has thus focused on satisfying demand by scaling up existing technologies, rather than investing in new technologies. Asian companies received significant investment in 2006 to expand the production of polysilicon and crystalline silicon modules in order to meet accelerated demand in Europe. However, intellectual property concerns have limited investment in innovative solar technologies in Asia, and it is unclear whether this barrier will persist for the near future. In the United States, start-up companies with novel technologies have attracted venture capital investment as relatively low electricity prices and current solar energy costs make significant market penetration in the U.S. presently out of reach, but attainable with technological development. While the German and Spanish feed-in tariffs have provided consistent and growing demand, they are markets with limited potential for driving long-term industry growth. Venture capital funds look for companies with high risk and high return potential. The U.S. energy market, with the possibility of hundreds of GWs of solar installations over the next couple of decades, certainly offers such potential. The more than $\$ 1$ billion of venture capital investment in U.S. solar companies in 2007 is a reflection of the numerous potential pathways to technological and market success.

The growth of venture capital investment in solar companies reflects the changing dynamics of innovation in the sector, from a government R\&D-dominated process to a more private sectordriven process. This trend does not portend an end to government-funded $\mathrm{R} \& \mathrm{D}$ in the solar sector, but it means that the role for government is to support the highest risk and value areas, including advanced materials science for the next generation of solar technologies, and to help develop the new frameworks required for distributed energy generation. For example, the DOE Solar America Initiative created a new framework for evaluating solar energy technologies in 2006 by focusing on the levelized cost of energy over the lifetime of a system. In 2008, the DOE is focusing its efforts on non-technical barriers to market entry, such as the policies, codes and standards of state and local governments and regulated utilities. To continue encouraging the growth of solar energy, the government could fund innovation for the next generation of photovoltaics, address the challenges of renewable system interconnections and further reduce the non-technical barriers to market entry. 


\section{Figure 8: Global Solar Venture Capital Rounds and Average Round Amount}

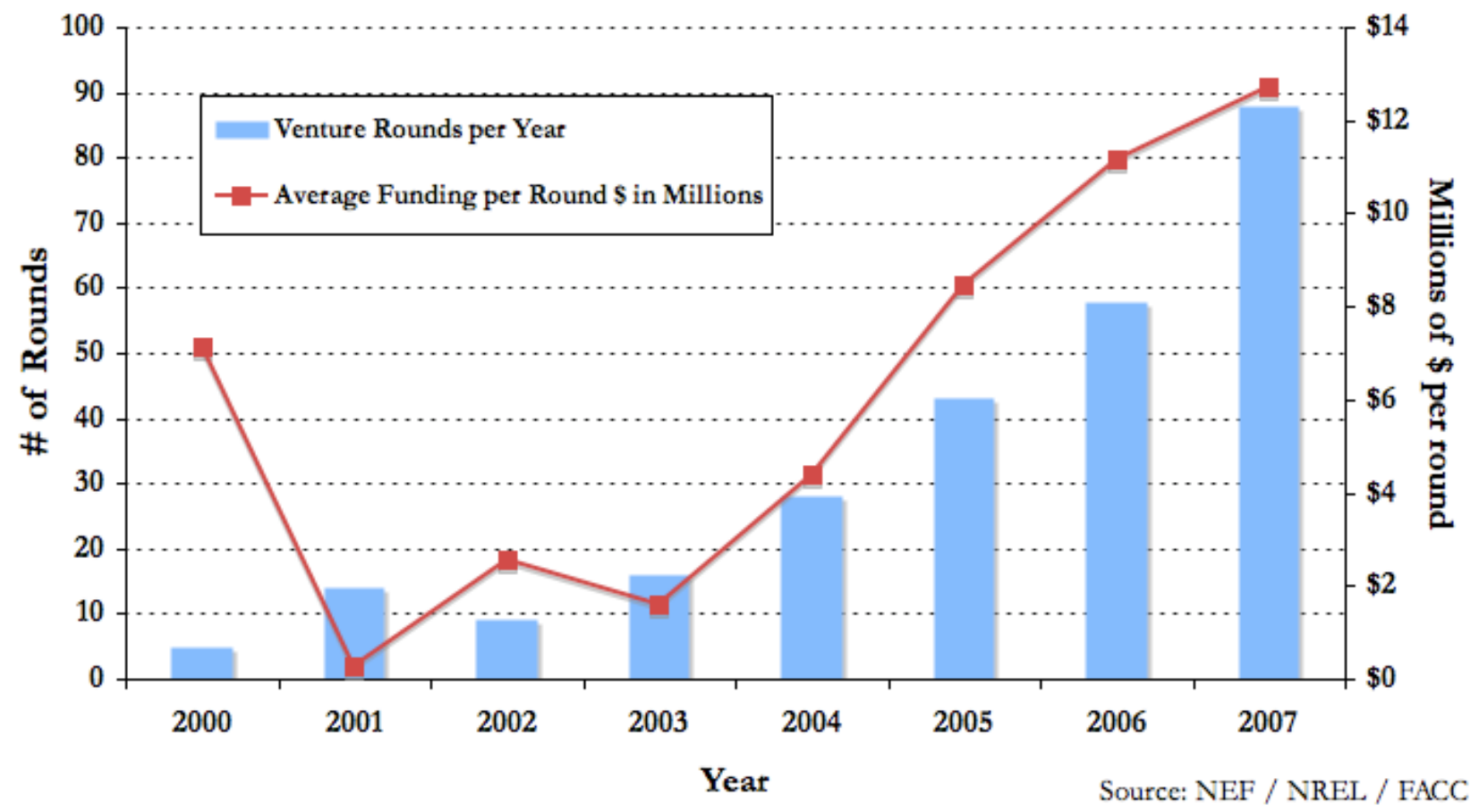

Figure 8 shows the growth from 2000 to 2007 in both the number of venture capital rounds (referring to the rounds of funding received by start-up companies) conducted per year and the average investment per round. The growth of venture capital funding reflects the increasing interest in the solar industry and signals forthcoming technological innovation.

The rise in average funding per round is a function of at least four market factors. First, as interest in a sector increases amongst venture capital investors, larger amounts of funding compete for the available deals. This expanded supply of capital may result in higher valuations and thus larger transaction sizes.

Second, as venture capital-backed companies mature, they typically need further rounds of funding to continue their growth to a size at which an initial public offering (IPO) or spin-off would be possible. Early rounds of funding are smaller and focused on R\&D and prototype development, whereas subsequent rounds of financing may be significantly larger, as they focus on scaling up the business. During these subsequent rounds, companies begin to hire management teams, build out pilot production lines and start product sales. The capital requirements are generally much greater for the later-round activities than for those needed to support initial technology development.

Third, the capital requirements for entry into the energy sector are substantially larger than those for the information technology (IT) industry that venture capital has traditionally financed. Venture capital investors have learned a great deal about the clean energy sector over the past few years, and thus the average deal size has increased as they have begun to understand the need for significant hard assets, such as manufacturing lines, to establish the value of a solar energy start-up company and enable investment exit through an IPO or other means. 
Finally, in the past three years, massive venture funding rounds may have skewed the average round amount upwards. Such funding included pre-IPO rounds of $\$ 80$ million for Suntech Power Holdings Company and \$68 million for Q-Cells AG in 2005 and the pre-IPO rounds of \$150 million for Yingli Green Energy Holding Company, \$100 million for China Sunergy Company and $\$ 53$ million for Solarfun Power Holdings in 2006. These deals were all essentially for scaling up the manufacturing of crystalline silicon cells and modules to meet increased worldwide demand. As such, they faced relatively low technology risk and offered a quick exit. A shift occurred in 2007, with large venture capital rounds for areas with higher technology risk, suggesting that venture capital investors have recognized the larger capital requirements and longer time to exit for innovative energy technologies. Large 2007 venture rounds included series B/second-round funding of \$100.5 million for HelioVolt Corporation, \$79.2 million for Solyndra, Inc. and \$63.6 million for SolFocus, Inc. as well as series D/fourth-round funding of \$50 million for Miasole, Inc and pre-IPO funding of \$61.3 million for Big Sun Energy Technology Incorporation. Except for the funding of Big Sun, all of these investments were for new technologies designed to decrease the cost of solar energy, including three thin film manufacturers and one concentrating photovoltaics (CPV) manufacturer.

\section{Figure 9: Global Solar Venture Capital Funding by Round Type}

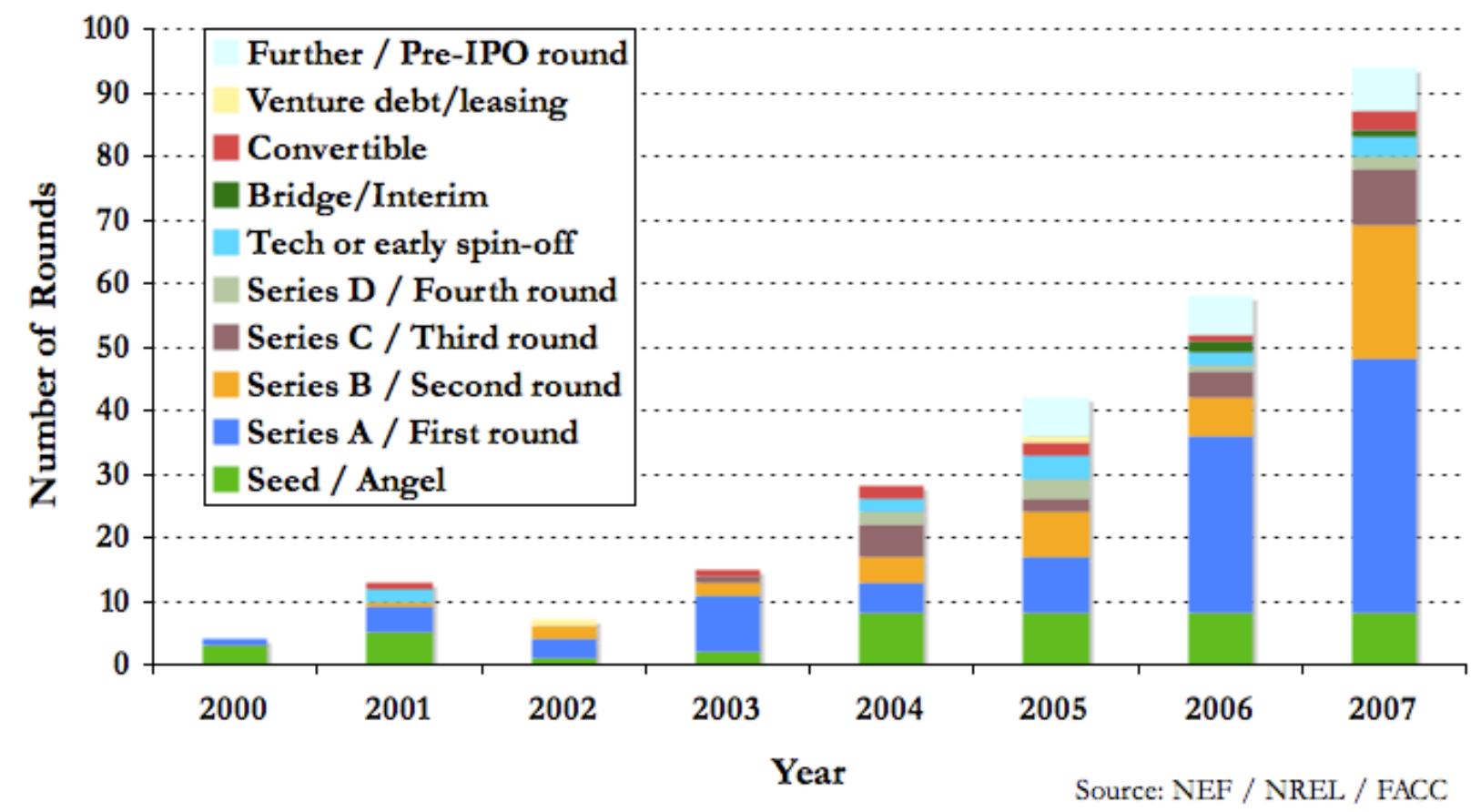

Figure 9 shows the number of venture capital rounds by type of round. The round types are arranged with the earliest round, Seed/Angel, at the bottom of the columns, and the latest round, PreIPO, at the top of the columns. This chart sheds light on whether the increase in average funding per venture capital round is a consequence of larger, later-stage investments being more prevalent in recent years. Recently, the largest increase in annual number of rounds has been in series A/firstround funding, rising from five deals in 2004 to 40 in 2007, followed by series B/second-round funding, which increased from four in 2004 to 21 in 2007. Evidently, most of the growth in the number of venture funding rounds over the past four years has been the result of new entrants into 
the solar industry, rather than older companies returning for additional capital to fund their growth. This trend signals the potential for significant future innovation in the solar industry.

As a general rule of thumb in venture capital funding, for every ten investments, there may be one or two companies that achieve major future success. If this proportion holds true for the 99 solar companies that received first-round funding over the past 8 years, 10-20 sizeable and influential solar companies will emerge during the next few years. Furthermore, within the vast market for solar energy, there are diverse applications for which different technologies may have strong competitive advantages. Therefore, it is likely that within the next three to five years, multiple solar technologies will enter and compete successfully in the marketplace.

\section{Private Equity Investment in Solar}

\section{Figure 10: Global Private Equity Investment in Solar}

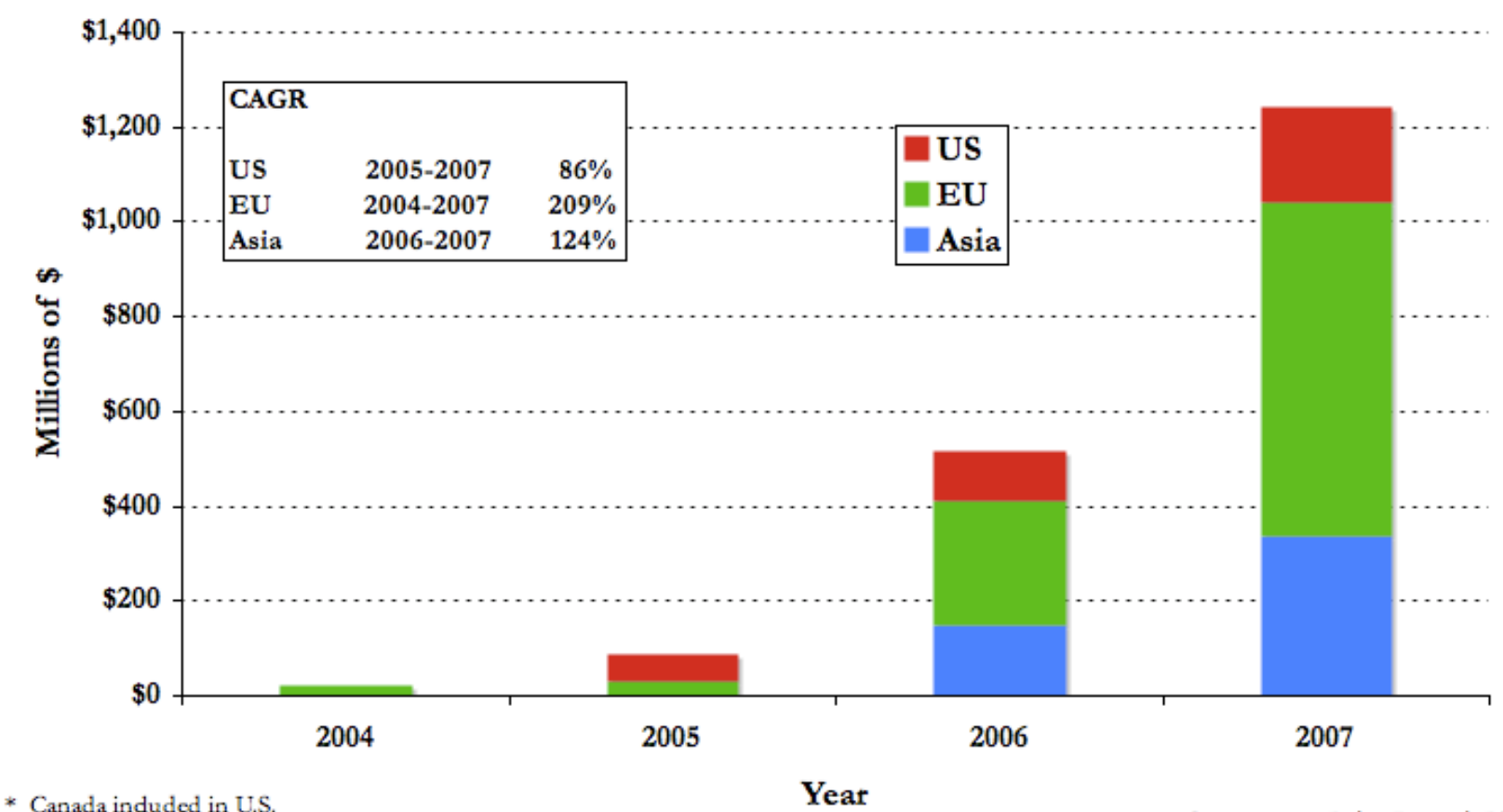

* Canada induded in U.S.

** Isracl induded in EU

Source: NEF / NREL / FACC

Figure 10 shows private equity investment in solar by region, as determined by the location of the company's headquarters. Through the end of 2007, this approach does not differ substantially from an analysis using the location of manufacturing facilities. In 2008 and beyond, adjustments would have to be made for the financing of overseas manufacturing expansions, such as First Solar's facilities in Malaysia, SunPower's facilities in the Philippines and Q-Cells' planned expansion in Mexico. However, all U.S. and EU companies currently planning overseas manufacturing expansions are publicly-owned and are not receiving private equity to finance these expansions. Also, in 2008, there has been a substantial slowdown in the overall private equity market due to the prolonged crisis in the credit markets that began in August 2007. Currently, private equity firms 
lack the access to inexpensive capital that had been fundamental to their investment strategies. It remains to be seen how much and for how long the credit crisis will affect the private equity financing of solar companies.

Figure 10 is focused on 2004-2007 because of the massive changes in private equity investment in solar energy during this period. 2000-2003 has been omitted because there were only three transactions during this period, which occurred in 2002 and totaled $\$ 40$ million. Also note that $26 \%$ of disclosed private equity deals for the years shown were of undisclosed value, and therefore the actual value of deals is certainly somewhat higher than that shown in the chart. However, deals of undisclosed value are likely to be smaller transactions.

Figure 10 illustrates that private equity is increasing fairly evenly across the three major regions. The vast majority of private equity investment in the solar industry has been for asset acquisition and capacity expansion, often to build or enlarge a manufacturing facility. Over the past few years, the solar PV market has been undersupplied, and private equity firms have seen opportunities in financing existing producers to scale up their production facilities and take advantage of the price premiums. Other emerging trends in private equity deals involve the spin-offs of solar divisions within larger companies and the integration of solar companies across the supply chain. Over the next couple of years, these types of deals will likely become more frequent as existing solar companies consolidate across the value chain and conglomerates sell off solar divisions that are peripheral to their core business. 


\section{Private Investment by Technology Area}

\section{Figure 11: Global Venture Capital and Private Equity Investments by Solar Technology}

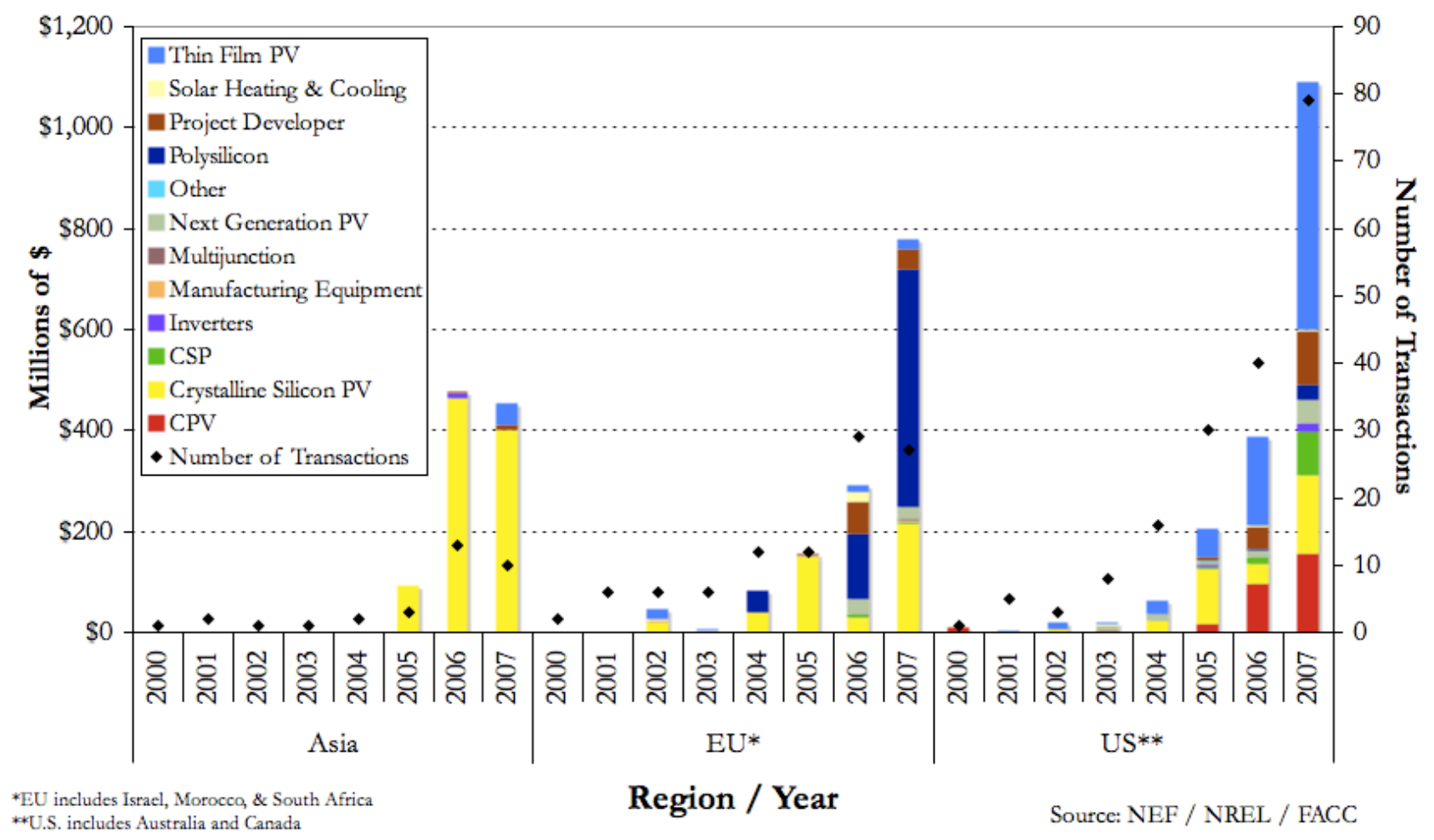

Figure 11 shows the value of private investment (both venture capital and private equity) in solar by year, region and technology on the left axis and the number of transactions by year and region on the right axis. Both of these measures are important because large deal values may indicate great interest in a certain area, whereas a large number of small deals may indicate interest in the technology but not enough perceived market demand for ambitious business plans. In addition, certain solar businesses, such as project developers, have lower capital requirements and/or margins, which can lead to a large number of deals of smaller value. Recall also that $21 \%$ of disclosed solar venture capital deals and $26 \%$ of disclosed private equity deals were of undisclosed value. The number of transactions is the only indication of investment in certain time periods and is also why not all of the technologies shown in the key appear in the chart columns. Lastly, ROW investments, including transactions in Canada, Israel, Australia, Morocco and South Africa have been added to either the EU or U.S. regions for ease of display. Total ROW private investment grew from $\$ 0.8$ million in 2000 to $\$ 48.9$ million in 2007 , equal to just over $10 \%$ of Asia's total private investment in that year.

The chart shows the nascent state of private investment in solar companies, with few transactions of variable size prior to 2004-2005. In 2000, there was a major CPV deal, Energy Innovations, but little else, while in 2001, the number of transactions increased in the European Union and United States, but the deal values were either very small or not disclosed. In 2002, there were two European deals in the \$20-million range and smaller deals in the United States focusing on 
crystalline silicon and thin-film technologies. Finally, in 2003, a diversity of technologies emerged amongst private investment deals, with project developers, manufacturing equipment, nextgeneration PV, polysilicon, CPV and thin film PV receiving investment in both the United States and European Union. Still, U.S. private investment included a more diverse set of companies than investments in other parts of the world.

Even with venture capital and private equity deals grouped together, the regional differences of investment in solar energy are strikingly apparent. Private investments in Asia were almost nonexistent until 2005 and have remained strongly focused on the production of crystalline silicon PV. Private investment in Europe started a little earlier, and has focused on crystalline silicon PV and polysilicon production, with additional interest in project developers and thin-film technologies in recent years. In contrast, U.S. private investment is a broadly diversified, with investments in nearly all areas of the solar industry and increasing interest in CPV, next-generation PV, concentrating solar power (CSP) and project developers. Most importantly, of the $\$ 552$ million of global private investment that thin film PV received in 2007, \$488 million went to U.S.-based companies.

Examining venture capital and private equity investments separately by year, region and technology provides additional insight into the nature of these investments. 


\section{Figure 12: Global Venture Capital Investment by Solar Technology}

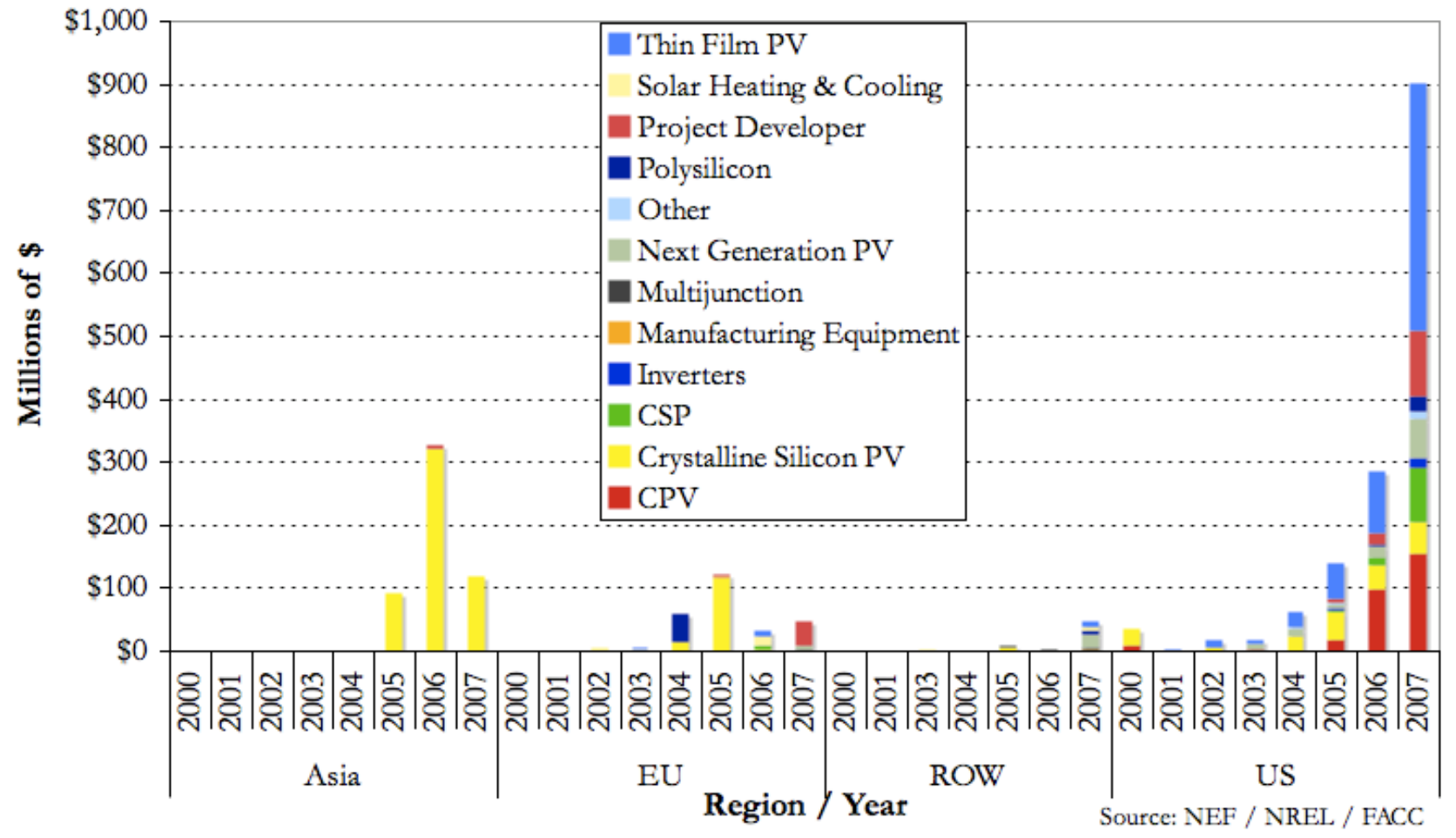

Figure 12 reinforces the trends seen in the overview chart of venture capital investment (Figure 7). During the past few years, very little growth has occurred in the venture capital funding of European solar companies. In Asia, nearly all venture capital investments went to producers of crystalline silicon PV. For ROW in 2007, the total of $\$ 48.9$ million consisted of $\$ 20.8$ million in next-generation PV, \$10.8 million in thin film PV and investments of between $\$ 1$ and $\$ 6$ million in polysilicon, solar heating and cooling, manufacturing equipment, multijunction cells and CPV. Venture capital investment may increase in Canada, Israel and Australia in the coming years, as these countries are hubs for technology innovation and have reasonably strong political and policy support for solar energy development.

The U.S. venture capital mix was very similar to the U.S. private investment mix in Figure 11 due to the dominance of venture capital in the U.S. U.S. venture capital investments have increased and diversified from \$35 million in crystalline silicon PV and CPV in 2000 to $\$ 902$ million in a broad selection of industry technologies in 2007, including CPV, crystalline silicon PV, CSP, inverters, next-generation PV, polysilicon and thin film PV, a CAGR of 59\%. The increase and diversification of venture capital funding suggests that significant innovation across many areas of solar energy should occur in the near future. Furthermore, the diversity of technologies receiving funding in the U.S. and abroad reflects the potential for many successful companies with different technologies, each providing specialized solutions for distributed, centralized or future hybrid models of electricity generation. 


\section{Figure 13: Global Private Equity Investment by Solar Technology}

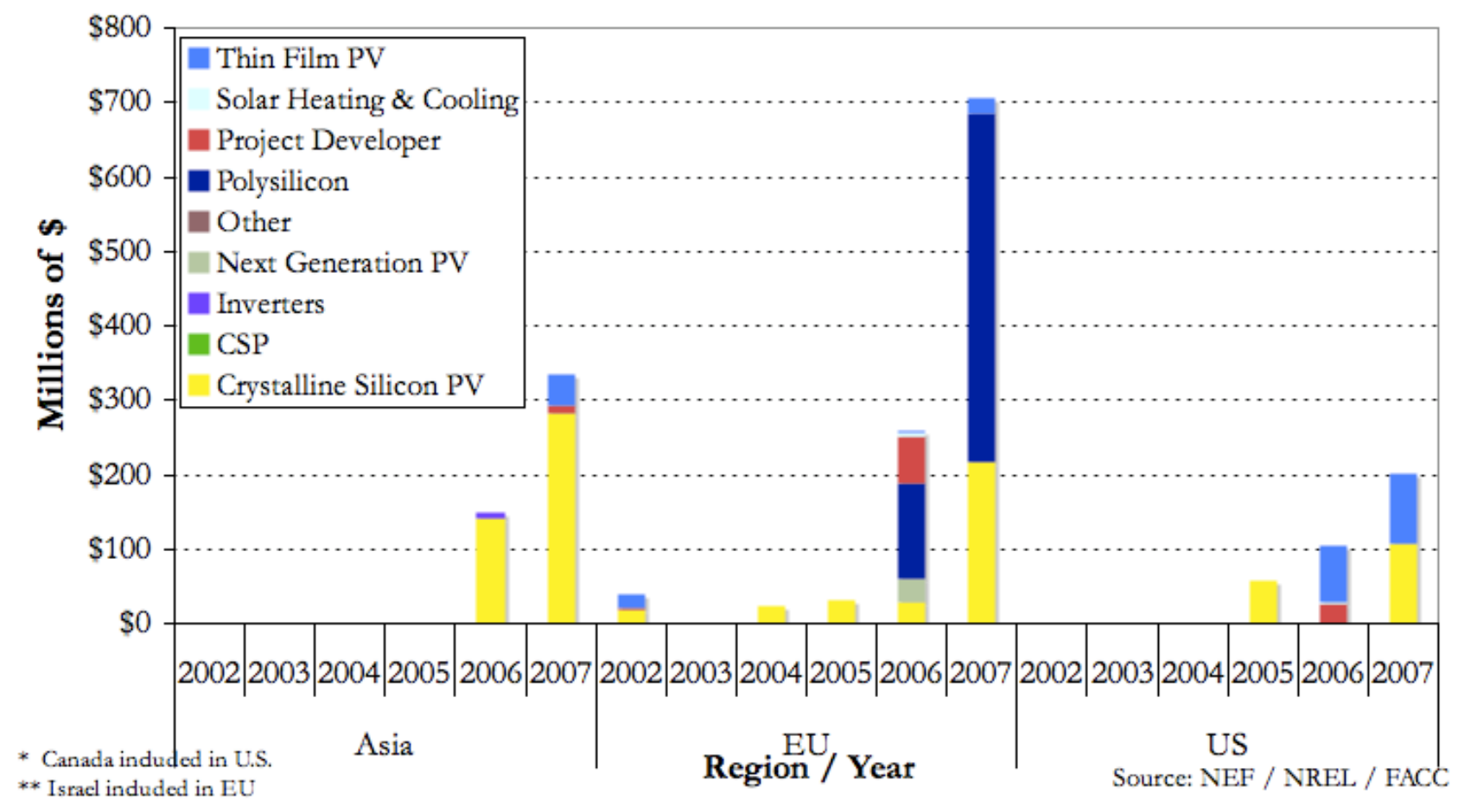

In contrast to venture capital shown in Figure 12, private equity is a newer source of funding to solar companies, with the first deals in the United States and Asia occurring in 2005 and 2006, respectively. Private equity investments are generally larger and therefore not allocated as broadly as venture capital investments. The differences in timing and technology allocation between venture capital and private equity funding are mostly attributable to the characteristics of private equity investments in the solar industry, which often fund production capacity expansions. Companies that require broad expansions to meet increased demand are the recipients of most private equity investments, and thus the smaller number of solar technologies that are proven and ready for manufacturing scale-up receive a disproportionately large share of private equity investment.

An example of this funding model is the case of Advent Solar, which raised (i) a venture-A round of funding of $\$ 0.8$ million in 2003 to start the company; (ii) a venture-B round of $\$ 8$ million in 2004 to further develop its technology; and (iii) a venture-C round of $\$ 30$ million in 2005 to build a 25-MW pilot manufacturing line. Advent Solar then transitioned to private equity with funding of $\$ 80$ million in 2007 to finance the building and ramp-up of its first commercial production line.

On a regional level, there were large private equity investments in crystalline silicon PV production in Asia, with some thin film PV investment in 2006-2007. In the European Union, early private equity investment in crystalline silicon $\mathrm{PV}$ has grown to include expansions in polysilicon supply in response to the shortage of the material, with 2006 and 2007 funding to Norsun AS, SiC Processing AG and Silicium de Provence SAS. There was also significant European private equity investment in four project developers and three thin film PV manufacturers in 2006 and in another PV thin film manufacturer in 2007. 
In the U.S. market, private equity investments did not start until 2005. Since then, they have focused on crystalline silicon PV manufacturers, thin film PV manufacturers and project developers.

\section{Private Investment in Solar Conclusions:}

Significant differences exist between the purpose, risk/reward profile and timing of venture capital and private equity investments, which result in different opportunities that are pursued. Venture capital investors in the solar industry pursue innovative technologies and have a high tolerance for risk. These investors have also begun to tolerate longer exit times in the solar industry, as evidenced by the more than 10 first-round investments in next-generation PV over the past few years that will take a minimum of seven years to get to market. In contrast, private equity investors in the solar industry have pursued established technologies with larger capital requirements, lower risk profiles and a somewhat faster expected exit time.

Significant regional differences also exist between venture capital and private equity investments and the technologies they fund, which are attributable to policy differences and production specialization. Both venture capital and private equity investments in Asia are primarily focused on crystalline silicon PV to take advantage of lower manufacturing costs without the intellectual property concerns of more innovative technologies. In Europe, private equity investment has rapidly expanded in response to increased demand for polysilicon and crystalline silicon PV to take advantage of the feed-in tariffs. However, the feed-in tariffs have also led to a dearth of venture capital investment in the region, as innovative products are not rewarded any more than the incumbent technology. In the United States, venture capital investment dominates, with innovative scientists and businessmen collaborating to pursue the technologies that will reduce costs, achieve scale and fit different applications across the country, which has the potential to be the world's largest solar market. Private equity investment in the United States is emerging as manufacturing facilities are expanded to meet demand that is subsidized by specific states. U.S. private equity investment could rise considerably if the federal government establishes a cap on carbon emissions or if further cost reductions enable solar technology to be more competitive with electricity delivered from the grid. 


\section{Mergers and Acquisitions in the Solar Industry}

Figure 14: Global Merger and Acquisition Activity in Solar

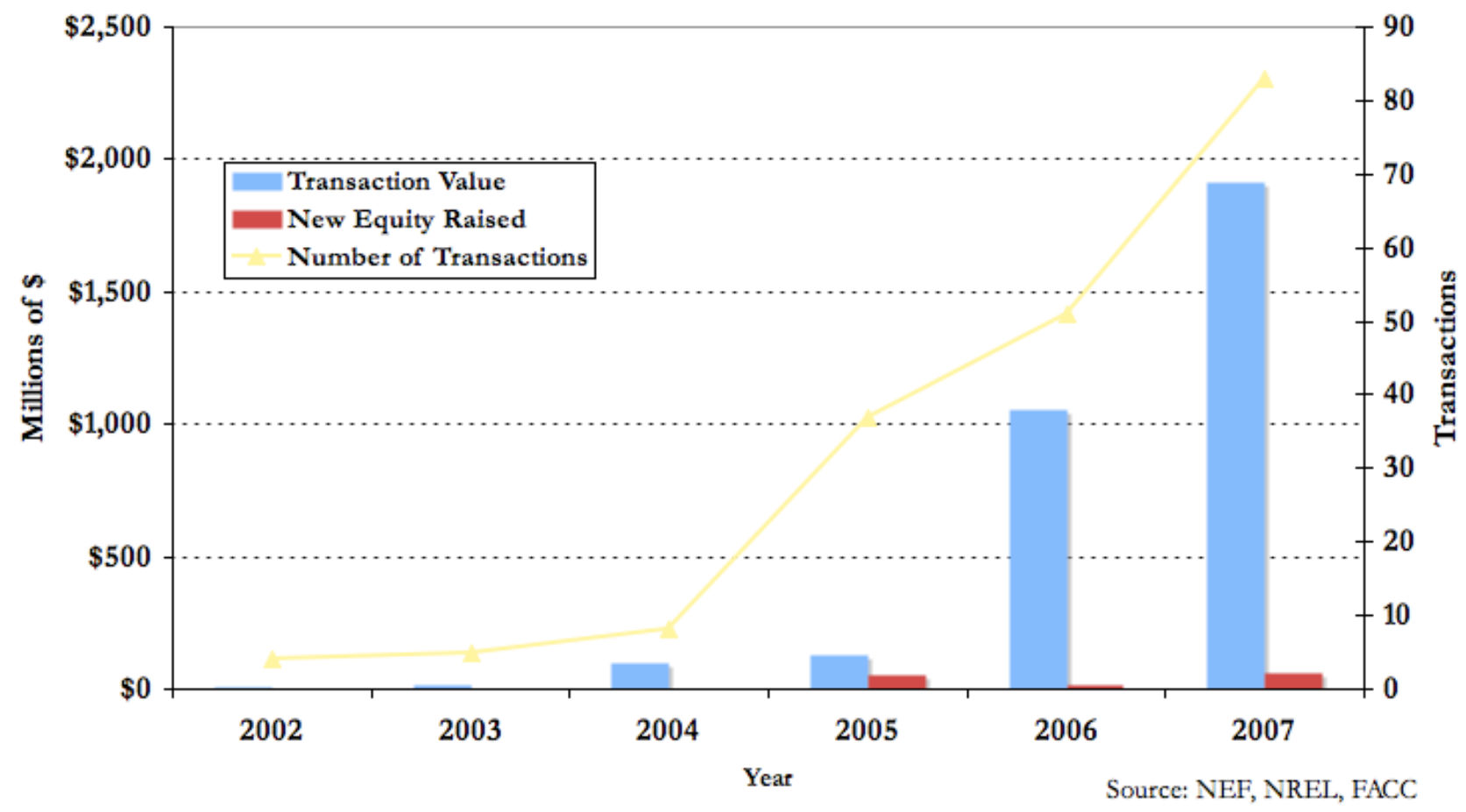

Figure 14 shows the total transaction value of mergers and acquisitions (M\&A), new equity raised for those transactions and the number of $\mathrm{M} \& \mathrm{~A}$ transactions per year globally in the solar industry. Disclosed M\&A deals raised new equity of $\$ 49.5, \$ 13.8$ and $\$ 58.6$ million from 2005 to 2007, sequentially. Based on industries growing at similar rates, further spin-offs and consolidations in the coming years should increase M\&A activity in the solar industry.

M\&A activity is still in a nascent stage, with larger companies starting to make acquisitions to integrate their operations across the supply chain, thereby gaining more control over their feedstock-supply or downstream distribution costs. Deal volume surpassed \$1.9 billion in 2007, with such large transactions as Applied Materials' acquisition of HCT Shaping Systems SA for \$475 million, SunPower's acquisition of PowerLight for \$332.5 million, DC Chemical's \$166 million investment in Evergreen Solar, E-Ton Solar's acquisition of Adema Technology for \$153.7 million and Multiutility's \$146.5 million investment in X-Group. Although such transactions have increased in size and number over the past few years, they have not yielded much new investment for the sector. This is an important distinction for M\&A transactions, in which equity is often only transferred between market participants, generating no new investment in the solar sector.

While our focus is on investment in solar energy technologies, M\&A activities are likely to have increasing impacts on the industry in the coming years, whether they result in new investment or not. Three main deal types are emerging in the industry: 
1. Established semiconductor companies enter the solar industry to leverage their manufacturing experience, and they acquire technology and core competencies from existing solar companies. Examples of this type include Applied Materials, Wacher Chemie, DC Chemical and MEMC Electronic Devices.

2. Established energy companies enter the solar industry to capitalize on their experience in the energy sector. Examples of this type include Norsk Hydro, Nippon Oil and Sichuan Energy. However, this strategy did not succeed for Shell or BP, both of which had been leaders in the photovoltaic industry at one time. Shell sold its solar business to SolarWorld, and BP Solar's growth has not kept pace with that of the industry.

3. Solar companies integrate or build strategic partnerships across the supply chain, either upstream (polysilicon and wafering), downstream (services and installations) or in valueadded companies (tracking or automation equipment). Examples of this type include SunPower's acquisition of PowerLight and First Solar's acquisition of Turner Renewables.

These types of transactions are emerging as the market for solar energy technologies is experiencing rapid growth. Companies with interest and understanding of the sector are trying to establish their presence and grow their market shares by capitalizing on first-mover advantages. In the future, some of these transactions may unwind, as occurred with Shell's solar business. Competition between existing manufacturing and energy firms for the intellectual property and business models in the solar industry will likely intensify, thereby raising valuations. Expansionary M\&A transactions and subsequent reversals, as well as increased competition for IP and business models, are characteristic of a new and rapidly growing industry. 


\section{Public Investment in the Solar Industry}

\section{Figure 15: Global Valuations of Completed Solar Public Offerings}

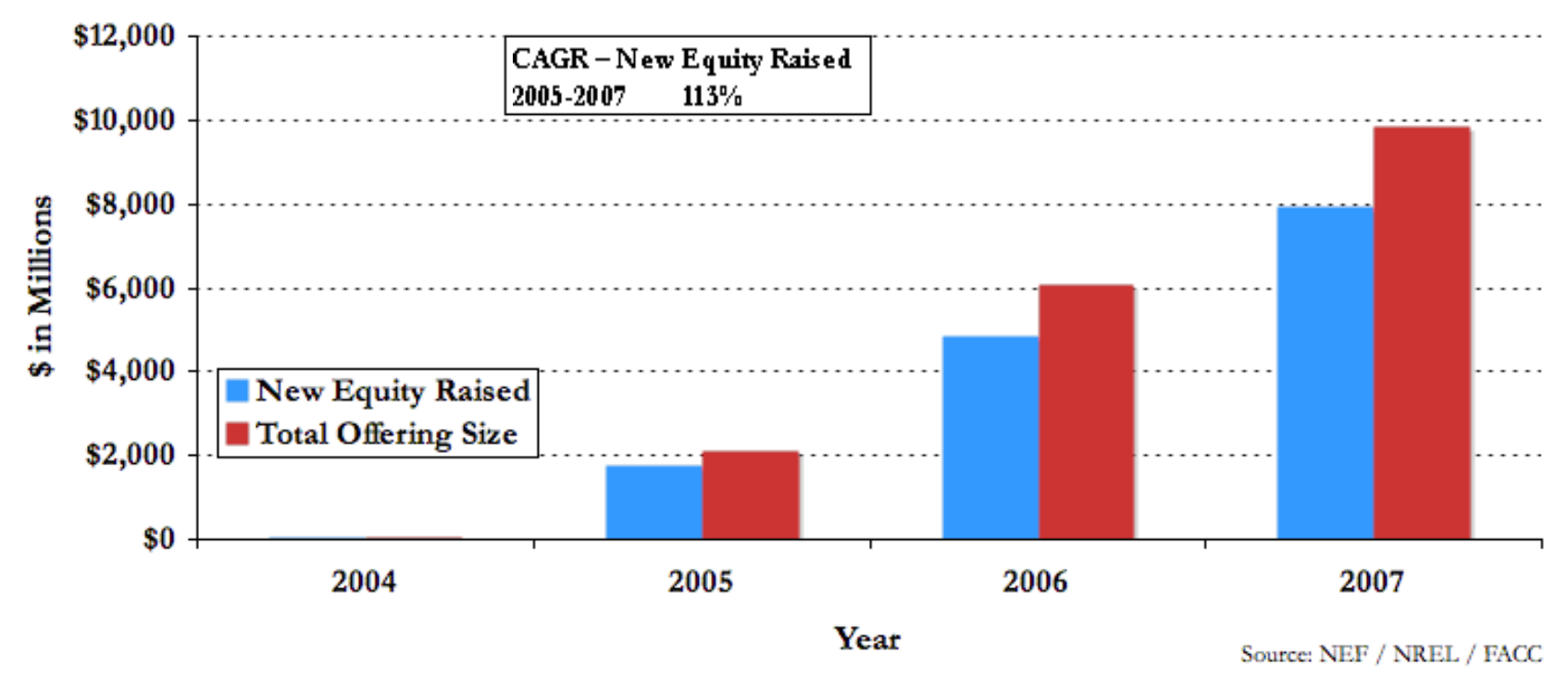

Figure 15 shows that public equity offerings of solar companies were extremely limited in 2004 , but in $2005, \$ 1.74$ billion of new equity was raised, followed by $\$ 4.83$ billion and $\$ 7.92$ billion in 2006 and 2007, respectively. In contrast, during the 2000-2004 period, public equity investment ranged from $\$ 12.1$ to $\$ 59.4$ million. It is clear that many things changed in 2005 : Germany's revised feed-in tariff took effect in 2004 and began to generate interest in solar, Japan's solar industry was experiencing steady growth while its subsidy programs were being phased out and the California Energy Commission (CEC) passed the California Solar Initiative (CSI) in December 2005. During the 2005-2007 period, new public equity dwarfed other types of investment in solar energy and grew at a $113 \%$ CAGR. This momentum may help to continue the growth of public equity investment despite far more challenging market conditions in 2008.

In Figure 15, the differences between new equity raised and total offering size are due to several factors. Most of the differences are the result of exits, in which the initial venture capital or private equity investors in the firm sell their shares to the public. Examples include Stroher Finanzholding's \$791 million exit of Q-Cells in 2006, Hafslund Ventures \$779 million exit of REC in 2007 and the Walton family's sale of $\$ 237$ million in First Solar equity in the company's August 2007 secondary offering. In addition, the companies' founders may sell some of their shares in secondary offerings.

Companies also raise debt as part of their public offerings, usually in the form of convertible bonds, which are included in the total offering size because they have the potential to convert into shares of the company at a later date. At the time of the public offering, however, they are not considered to be equity because, as bonds, they have the expectation of repayment. A recent example is Yingli Green Energy Holding Company's issuance of \$173.6 million of convertible bonds in conjunction with its follow-on offering of \$150 million of new equity in December 2007. 


\section{Figure 16: Global Solar Public Offerings by Status}

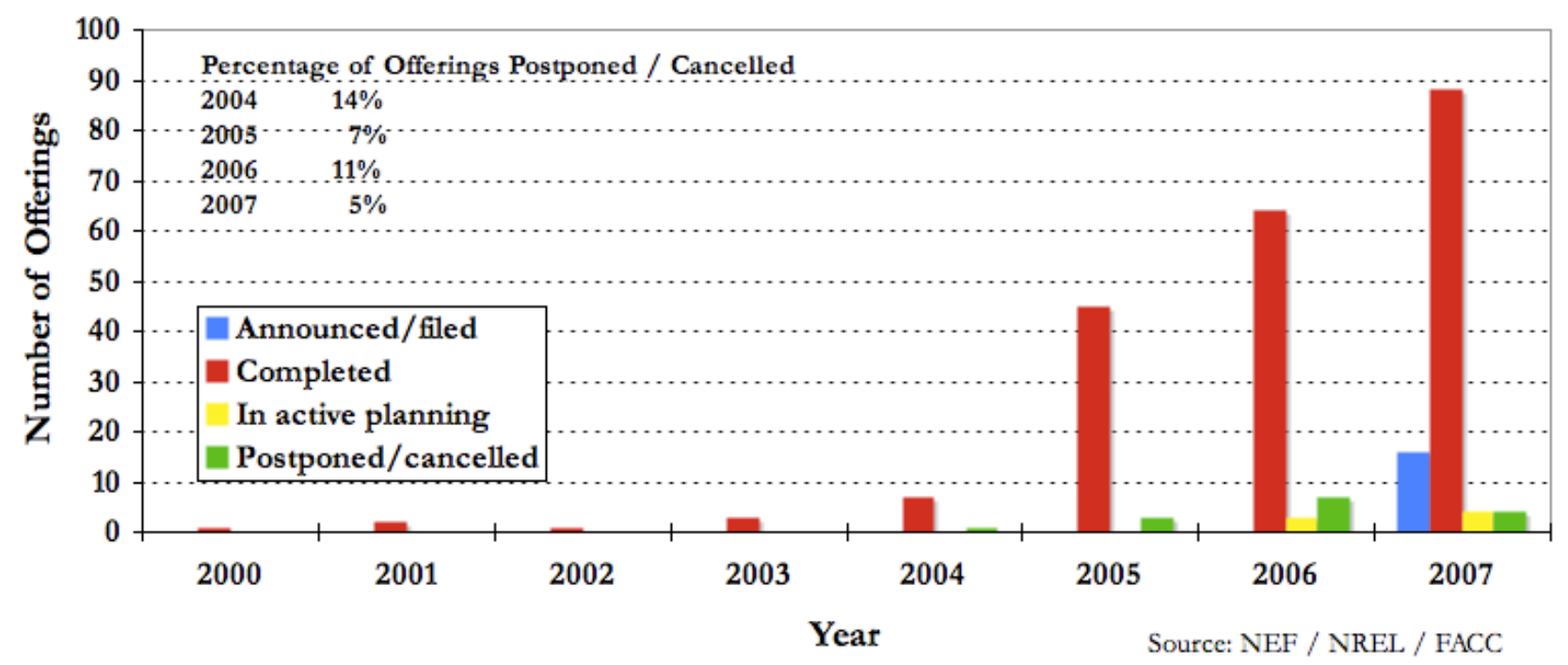

Figure 16 shows the status of public equity offerings of solar companies. There were only a few offerings per year in the 2000-2003 period, and not until 2004, when there were seven offerings, was there a postponed or cancelled public offering. From 2005 to 2007, public offerings of solar companies grew rapidly, with 45, 64 and 88 offerings, sequentially, in those years. The increasing number of public offerings and the rather low percentage of postponed/cancelled offerings indicate strong market demand for solar company stocks. While the overall stock market has softened considerably since the fourth quarter of 2007, successful public offerings of solar companies continued into Q1 2008. However, difficult market conditions in 2008 may prevent solar companies without significant revenues from entering the public equity markets. In the first quarter of 2008, there was a significant slowdown compared to 2007 , with $\$ 1.1$ billion raised in 17 completed public equity offerings, most of which were secondary issues rather than initial public offerings. 


\section{Figure 17: Performance of Solar Photovoltaic Stocks}

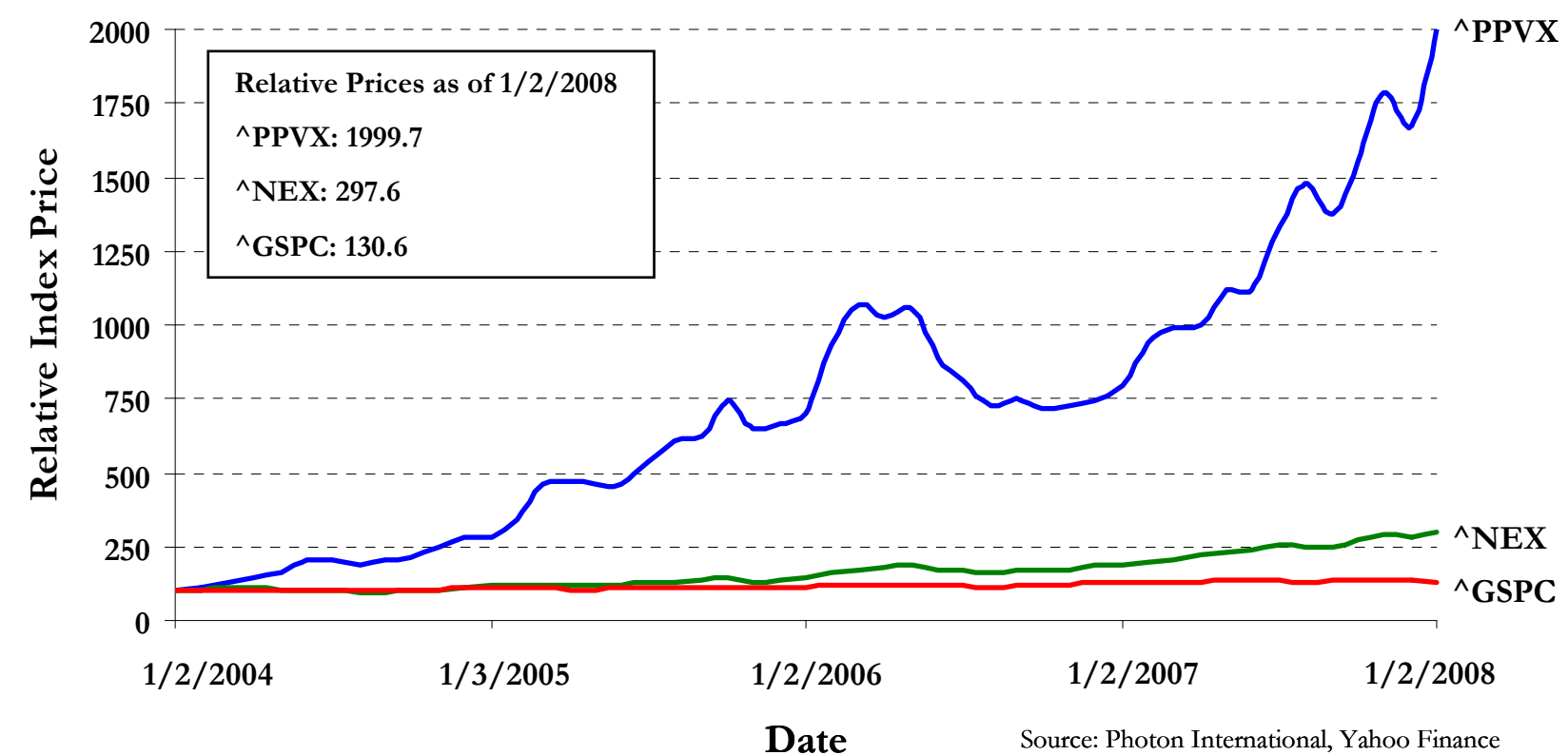

Figure 17 illustrates the performance of public solar photovoltaic equities from 2004 through the beginning of 2008. ${ }^{6}$ The Photon Photovoltaic Stock Index (^PPVX) is a weighted index of companies which derive at least $50 \%$ of their revenues from photovoltaic products and services. For comparison, we include the WilderHill New Energy Global Innovation Index (^NEX), which contains a variety of clean energy technologies, as well as the S\&P 500 Index $(\wedge$ GSPC), with each index set to 100 at the beginning of 2004. At the beginning of 2008, the ${ }^{\wedge} \mathrm{PPVX}$ was worth about 20 times its value at the start of 2004, compared to approximately three times for the ${ }^{\wedge} \mathrm{NEX}$ and 1.3 times for the ${ }^{\wedge} \mathrm{GSPC}$. While the ${ }^{\wedge} \mathrm{PPVX}$ has declined substantially in 2008 (as have the ${ }^{\wedge} \mathrm{NEX}$ and ${ }^{\wedge} \mathrm{GSPC}$ ), its dramatic rise from the beginning of 2004 reflects increased investor interest during this period in solar photovoltaic companies and optimistic expectations about the industry's future.

\footnotetext{
${ }^{6}$ Concentrating solar power (CSP) is not included, as there have not been public companies with a majority of their revenues from CSP.
} 


\section{Table 1: Public Pure-Play Solar Companies—as of 03/31/2008}

\begin{tabular}{lll}
\multicolumn{1}{c}{ Company } & Stock Symbol & \multicolumn{1}{c}{ Type } \\
Akeena Solar & AKNS & Project Developer \\
Canadian Solar & CSIQ & Crystalline Si \\
China Sunergy Co. & CSUN & Crystalline Si \\
Energy Conversion Devices & ENER & Thin Film \\
Evergreen Solar & ESLR & Crystalline Si \\
First Solar & FSLR & Thin Film \\
JA Solar Holdings & JASO & Crystalline Si \\
LDK Solar Co., Ltd. & LDK & Crystalline Si \\
ReneSola, Ltd. & SOL & Crystalline Si \\
SolarFun Power Holdings & SOLF & Crystalline Si \\
SunPower Corp. & SPWR & Integrated \\
SunTech Power & STP & Crystalline Si \\
Trina Solar Ltd. & TSL & Crystalline Si \\
MEMC Electronic Materials & WFR & Polysilicon \\
Yingli Green Energy Holding Co., Ltd. & YGE & Crystalline Si \\
Conergy & CGY.DE & Project Developer \\
Q-Cells & QCE.DE & Crystalline Si \\
Solar Fabrik & SFX.DE & Crystalline Si \\
Solaria Energia & SLR.MC & Integrated \\
Solon AG & SOO1.DE & Crystalline Si \\
SolarWorld & SWV.DE & Crystalline Si \\
ERSOL & ES6.DE & Crystalline Si \\
Wacker Chemie & WCH.DE & Polysilicon \\
Renewable Energy Corporation & REC.OL & Crystalline Si \\
& & \\
\hline & &
\end{tabular}

Table 1 provides a snapshot of public pure-play solar companies, those with businesses focused entirely, or almost entirely, on one or more areas of solar energy. Of the 24 companies listed in Table 1, 16 are crystalline silicon PV manufacturers, two are polysilicon producers, two are project developers, two are thin film PV manufacturers and two are integrated companies, which cover the value chain from cell fabrication to device installation. The two polysilicon producers, Wacker Chemie and MEMC Electronic Devices, are the only non-pure-play companies included in Table 1. Both of these companies make polysilicon and silicon wafers for both the semiconductor and solar industries, and in 2006, the solar industry surpassed the semiconductor industry to become the majority consumer of polysilicon wafers. Although the portions of these companies' revenues and earnings derived from their solar businesses varies, solar is becoming an increasingly important part of their overall businesses. 


\section{Figure 18: Global Solar Industry Revenues and Operating Profits}

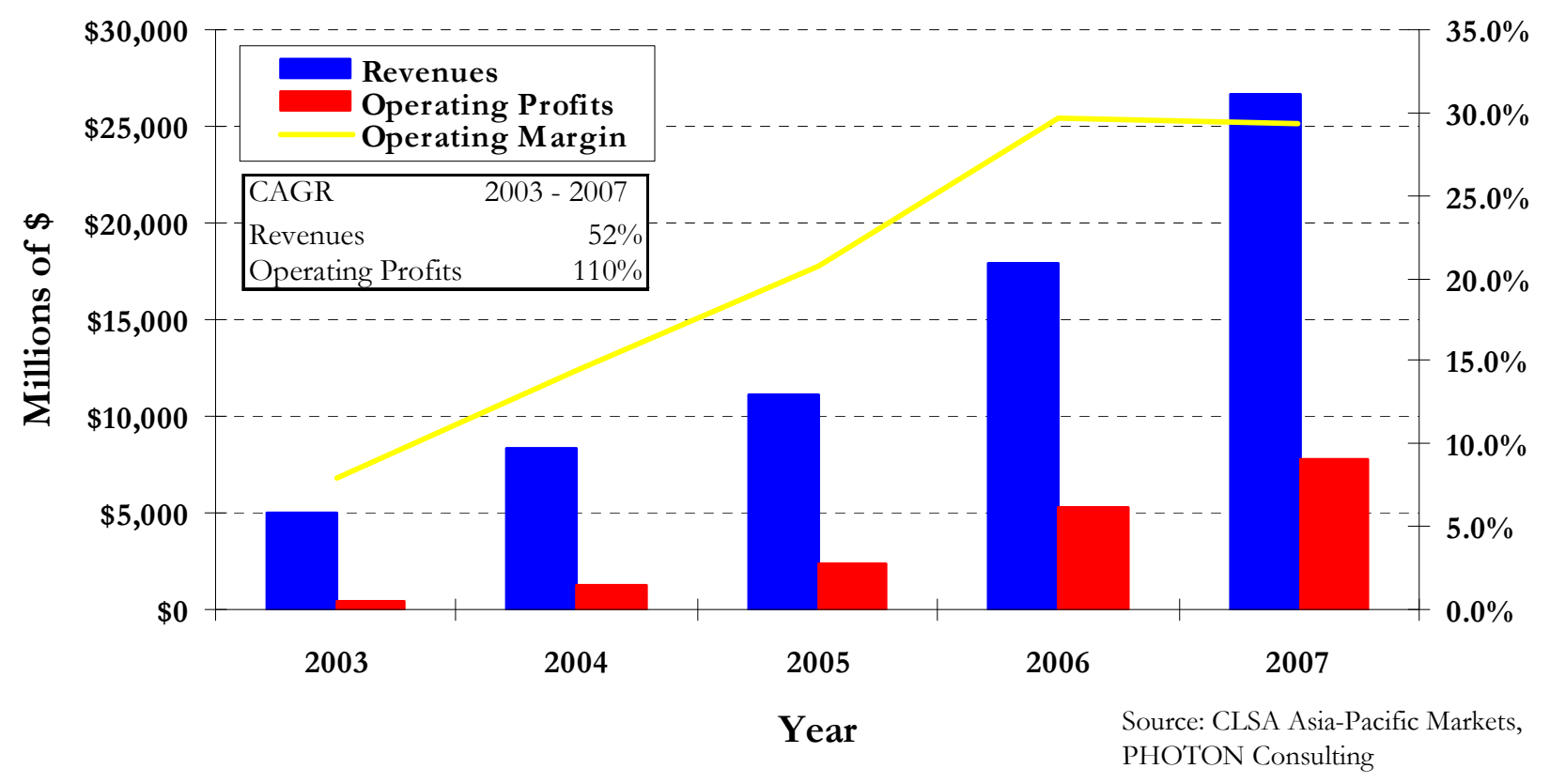

Figure 18 shows the total revenues, operating profits and operating profit margin for the global solar energy industry. Total revenues increased at a CAGR of 52\%, from about $\$ 5$ billion in 2003 to almost $\$ 27$ billion in 2007. Total operating profits rose even faster, from $\$ 400$ million to $\$ 7.8$ billion (a CAGR of $110 \%$ ), as operating margins expanded from $8 \%$ to $29 \%$ during this period.

As these figures are for the entire industry, the operating profit margin is a blend, primarily of crystalline silicon and thin film technologies. In 2007, the crystalline silicon sector had an operating margin of $33 \%$, in comparison to $7 \%$ for the thin film sector. ${ }^{7}$ The increase of thin film as a percentage of total solar revenues in 2007 explains the slight drop in overall solar operating margins, from $29.6 \%$ in 2006 to $29.3 \%$ in 2007.

With the strong and consistent growth of its revenues, operating profits and operating profit margins, the solar industry has established an impressive financial track record, which is crucial for continued expansion of public and private investment.

\footnotetext{
${ }^{7}$ Source: PHOTON Consulting
} 


\section{Conclusion}

The growth of total investment in solar energy technologies has been tremendous during 2000-2007, mostly due to the rapid growth over the last four years. Each of the three types of new investment that we examined, venture capital, private equity and public equity, grew at a CAGR of over $100 \%$ from 2004 to 2007 . Additionally, private and public funding to solar companies increased vastly in each of the three main regions, the U.S., E.U. and Asia.

Coinciding with the progress of many solar energy technologies from the laboratory to pilot and full-scale production, over time later and larger sources of financing have risen as a percentage of total investment. Thus by 2007 public equity accounted for almost two-thirds of global nongovernmental investment in solar energy, and private equity surpassed venture capital investments in solar energy for the first time. However, the fact that a majority of venture capital rounds in 2007 were either series $\mathrm{A} /$ first round or series $\mathrm{B} /$ second round reflects the continued importance of startup companies with novel technologies. Also notable is the diversity of solar energy technologies receiving venture capital funding, in particular, in the U.S.

Regionally, investment trends reveal differences in manufacturing costs, intellectual property protections and policy support. In Asia, with low manufacturing costs but also low intellectual property protection, investment has been towards expanding production of crystalline silicon PV. In Europe, feed-in tariffs have provided support for investment in incumbent technologies, mostly crystalline silicon PV and polysilicon. Finally, without subsidies as generous as in Europe but with good intellectual protection and established research/business collaboration, investors in the U.S. have been supporting a variety of technologies, including thin film PV, CPV, CSP and crystalline silicon PV.

Although overall public and private equity markets are likely to be less accessible in the near future, solar energy has established both a diversity of promising technologies and strong growth in revenues and operating profits and margins, which should help the industry continue to secure funding going forward. In addition, while government subsidies are currently essential for the sector, solar technologies offer continued cost reductions through multiple pathways, and immense market potential if these cost reductions can be realized. 


\section{List of Figures:}

\section{F i g u r e s}

$1 \quad$ U.S. DOE Solar Technology Development Pipeline

2 Positive Feedback for Solar

3 Global Capital Investments in Solar Energy

$4 \quad$ U.S. Capital Investments in Solar Energy

5 Global Venture Capital Investments in Clean Energy Technologies

6 Global Venture Capital and Private Equity Investments in Solar

7 Global Venture Capital Investment in Solar

8 Global Solar Venture Capital Rounds and Average Round Amount

9 Global Solar Venture Capital Funding by Round Type

10 Global Private Equity Investment in Solar Energy

11 Global Venture Capital and Private Equity Investments by Solar Technology

12 Global Venture Capital Investment by Solar Technology

13 Global Private Equity Investment by Solar Technology

14 Global Merger and Acquisition Activity in Solar

15 Global Valuations of Completed Solar Public Offerings

16 Global Solar Public Offerings by Status

17 Performance of Solar Photovoltaic Stocks

18 Global Solar Industry Revenues and Operating Profits

\section{T a b l e}

$1 \quad$ Public Pure-Play Solar Companies 


\section{Glossary of Acronyms:}

$\begin{array}{ll}\text { CAGR } & \text { compound annual growth rate } \\ \text { CEC } & \text { California Energy Commission } \\ \text { CPV } & \text { concentrating photovoltaics } \\ \text { CSI } & \text { California Solar Initiative } \\ \text { CSP } & \text { concentrating solar power } \\ \text { DOE } & \text { U.S. Department of Energy } \\ \text { EU } & \text { European Union } \\ \text { FACC } & \text { Financial Analytics Consulting Corporation } \\ \text { IP } & \text { intellectual property } \\ \text { IPO } & \text { initial public offering } \\ \text { IT } & \text { information technology } \\ \text { ITC } & \text { investment tax credit } \\ \text { M\&A } & \text { mergers and acquisitions } \\ \text { NEF } & \text { New Energy Finance } \\ \text { NREL } & \text { National Renewable Energy Laboratory } \\ \text { PE } & \text { private equity } \\ \text { PV } & \text { photovoltaics } \\ \text { R\&D } & \text { research and development } \\ \text { ROW } & \text { rest of the world } \\ \text { SETP } & \text { Solar Energy Technologies Program } \\ \text { U.S. } & \text { United States of America } \\ \text { USD } & \text { U.S. dollar } \\ \text { VC } & \text { venture capital } \\ & \end{array}$




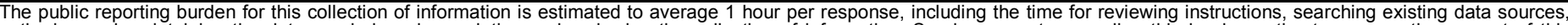

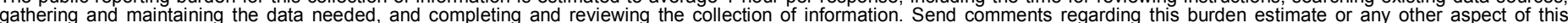

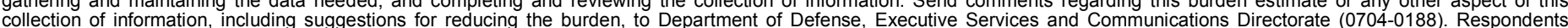

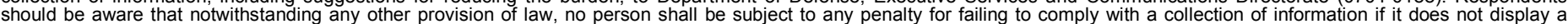

should be aware that notwithstanding

PLEASE DO NOT RETURN YOUR FORM TO THE ABOVE ORGANIZATION.

\begin{tabular}{l|l|l|l} 
1. REPORT DATE $(D D-M M-Y Y Y Y)$ & 2. & REPORT TYPE & 3. DATES COVERED (FrOm - TO)
\end{tabular}

December 2008

Technical Report

4. TITLE AND SUBTITLE

Historical Analysis of Investment in Solar Energy Technologies

(2000-2007)

5a. CONTRACT NUMBER

DE-AC36-08-GO28308

5b. GRANT NUMBER

5c. PROGRAM ELEMENT NUMBER

6. AUTHOR(S)

C.E. Jennings, R.M. Margolis, and J.E. Bartlett

5d. PROJECT NUMBER

NREL/TP-6A2-43602

5e. TASK NUMBER

PVB7.6301

5f. WORK UNIT NUMBER
7. PERFORMING ORGANIZATION NAME(S) AND ADDRESS(ES)

National Renewable Energy Laboratory

1617 Cole Blvd.

Golden, CO 80401-3393
8. PERFORMING ORGANIZATION REPORT NUMBER

NREL/TP-6A2-43602

9. SPONSORING/MONITORING AGENCY NAME(S) AND ADDRESS(ES)

10. SPONSOR/MONITOR'S ACRONYM(S)

11. SPONSORING/MONITORING AGENCY REPORT NUMBER

12. DISTRIBUTION AVAILABILITY STATEMENT

National Technical Information Service

U.S. Department of Commerce

5285 Port Royal Road

Springfield, VA 22161

13. SUPPLEMENTARY NOTES

14. ABSTRACT (Maximum 200 Words)

The solar energy industry experienced unprecedented growth in the eight years from 2000 to 2007 , with explosive growth occurring in the latter half of this period. From 2004 to 2007, global private sector investment in solar energy increased by almost twenty-fold, marking a dramatic increase in the short span of four years. This paper examines the timing, magnitude, focus and location of various forms of investment in the solar energy sector. It analyzes their trends to provide an understanding of the growth of the solar industry during the past eight years and to identify emerging themes in this rapidly evolving industry.

15. SUBJECT TERMS

solar energy; solar photovoltaics; PV; solar; rooftop PV; energy consumption; building technologies; residential buildings; solar systems; solar industry

16. SECURITY CLASSIFICATION OF:

a. REPORT

\begin{tabular}{l|l|l|l|l}
\hline & b. ABSTRACT & c. THIS PAGE
\end{tabular}

Unclassified Unclassified Unclassified

\begin{tabular}{|c|c|}
\hline $\begin{array}{l}\text { 17. LIMITATION } \\
\text { OF ABSTRACT }\end{array}$ & $\begin{array}{ll}\text { 18. } & \text { NUMBER } \\
\text { OF PAGES }\end{array}$ \\
\hline UL & \\
\hline
\end{tabular}

19a. NAME OF RESPONSIBLE PERSON

19b. TELEPHONE NUMBER (Include area code) 